Florida A\&M University College of Law

Scholarly Commons @ FAMU Law

2019

A Warrant Requirement Resurgence: The Fourth Amendment in the Roberts Court

Benjamin Priester

Follow this and additional works at: https://commons.law.famu.edu/faculty-research

Part of the Constitutional Law Commons, Criminal Law Commons, Criminal Procedure Commons, and the Evidence Commons 


\title{
A WARRANT REQUIREMENT RESURGENCE? \\ THE FOURTH AMENDMENT IN THE ROBERTS COURT
}

\author{
BENJAMIN J. PRIESTER ${ }^{\dagger}$
}

\section{INTRODUCTION}

Over many years, the United States Supreme Court has developed an extensive body of precedent interpreting and enforcing the provisions of the Fourth Amendment to the United States Constitution, which prohibits unreasonable searches and seizures by law enforcement agents conducting criminal investigations. Commonly called the "warrant requirement," one key component of this case law operates to deem some police investigatory techniques to be unconstitutional unless they are conducted pursuant to a search warrant issued in advance by a judge. The terms of the doctrine and its exceptions also authorize other investigatory actions as constitutionally permissible without a search warrant. The doctrinal framework created by the warrant requirement serves as a core foundational principle of the Court's constitutional criminal procedure for police investigations.

The conventional wisdom about the warrant requirement suggests that over the last half-century, the Court has moved from rigorously interpreting and enforcing the doctrine to reducing its importance and recognizing more exceptions for permissible warrantless searches. While this perspective has some descriptive accuracy in the aggregate, the past decade of the Roberts Court has produced a series of Fourth Amendment decisions, ranging across a variety of subsidiary doctrinal areas, where the warrant requirement has made a comeback-cases in which a criminal defendant has prevailed because the police lacked a search warrant when acquiring crucial evidence during

\footnotetext{
† Professor of Law, Florida Coastal School of Law.
} 
the investigation. A common thread among these decisions is the Roberts Court's confrontation of the Fourth Amendment implications of electronic surveillance, internet connectivity, data analytics, and other rapidly advancing technologies in the digital age. This resurgence of the warrant requirement cannot be readily dismissed as happenstance or coincidence, and consequently its development and its future ramifications are worthy of careful consideration.

\section{A. Doctrinal Foundations}

For many years, the warrant requirement has been the subject of considerable commentary and analysis, both in the opinions of the Court and among scholars. ${ }^{1}$ Reviewing the basic premises of the doctrine is helpful in establishing the framework for assessing the Court's recent cases.

Ratified in 1791, the Fourth Amendment accomplished two important objectives in repudiating certain practices by the Crown's agents which, along with many others, had helped to provoke the American Revolution. ${ }^{2}$ First, it prohibited "unreasonable" searches and seizures, ensuring a significant degree of protection for the security of individuals and their property against government intrusion. ${ }^{3}$ Second, it abolished the general warrants and writs of assistance despised by the Founders, instead restricting the issuance of warrants to those supported by an evidentiary basis in probable cause and circumscribed by particularity in location, target, and subject matter. ${ }^{4}$ The relationship between these two clauses of the

1 See David Gray, Fourth Amendment Remedies as Rights: The Warrant Requirement, 96 B.U. L. REV. 425, 425-36 (2016) (citing and discussing prominent arguments for and against warrant requirement). See generally Akhil Reed Amar, Fourth Amendment First Principles, 107 HARV. L. REV. 757 (1994); Phyllis T. Bookspan, Reworking the Warrant Requirement: Resuscitating the Fourth Amendment, 44 VAND. L. REv. 473 (1991); Carol S. Steiker, Second Thoughts About First Principles, 107 HARV. L. REV. 820 (1994). For a thorough summary of the current state of the doctrine and its exceptions, see The Warrant Requirement, 46 GEO. L.J. ANN. REV. CRIM. PROC. 25 (2017).

${ }^{2}$ See, e.g., Carpenter v. United States, 138 S. Ct. 2206, 2239-40 (2018) (Thomas, J., dissenting); Riley v. California, 573 U.S. 373, 402 (2014).

${ }_{3}$ See, e.g., Carpenter, 138 S. Ct. at 2239-41 (Thomas, J., dissenting); id. at 2243-44 (arguing that, at the time of the Founding, the use of the word "unreasonable" in the Fourth Amendment "likely meant" to proscribe searches "against the reason of the common law"); Riley, 134 S. Ct. at 2482-84.

${ }^{4}$ See, e.g., Carpenter, 138 S. Ct. at 2239-40 (Thomas, J., dissenting); Riley, 573 U.S. at 381-83. 
Fourth Amendment serves as a core underlying issue in debates over the Court's warrant requirement doctrine. ${ }^{5}$

The warrant requirement became prominent during the 1960 s and 1970s, when the Court's decisions rapidly expanded the doctrinal scope of constitutional criminal procedure. ${ }^{6}$ In numerous opinions, the Court has stated the requirement in these terms: a warrantless search is presumptively unreasonable in violation of the Fourth Amendment. ${ }^{7}$ Although the Court in the same period recognized a variety of situations in which that presumption could be overcome-such as the presence of exigent circumstances, the discovery of evidence of a crime in plain view, or a temporary "stop and frisk" detention short of custodial arrest ${ }^{8}$ - this doctrinal formulation established an important procedural distinction for litigating motions to suppress evidence. When the police discover evidence pursuant to a search warrant, the burden is on the defendant to prove that the warrant was constitutionally defective in its issuance or that the police impermissibly exceeded the scope of search authorization contained in an otherwise duly issued warrant. ${ }^{9}$ Neither is easy to do, but the former is especially difficult. ${ }^{10}$ On the other hand, when the police discover evidence without a warrant, the burden falls on the government to establish by a preponderance of the evidence that an exception to the warrant requirement applies to

${ }^{5}$ See generally JOSHUA DRESSLER, ET AL., 1 UNDERSTANDING CRIMINAL PROCEDURE $\S 10.01$ (7th ed. 2017); Gray, supra note 1. See also Groh v. Ramirez, 540 U.S. 551, 571-73 (2004) (Thomas, J., dissenting).

${ }^{6}$ See, e.g., Tracey Maclin, The Central Meaning of the Fourth Amendment, 35 WM. \& MARY L. REV. 197, 204-05 (1993); see infra Part I.B. The expansion reached well beyond the Fourth Amendment and the warrant requirement. See, e.g., Miranda v. Arizona, 384 U.S. 436, 471-72 (1966) (requiring advice of rights and valid waiver of rights prior to custodial police interrogation); Gideon v. Wainwright, 372 U.S. 335, 344 (1963) (requiring representation by counsel at trial for felony defendants).

7 See, e.g., Kyllo v. United States, 533 U.S. 27, 32 (2001).

${ }^{8}$ See Coolidge v. New Hampshire, 403 U.S. 443, 465 (1971) (plain view); Terry v. Ohio, 392 U.S. 1, 16, 30 (1968) (stop and frisk); Warden v. Hayden, 387 U.S. 294, 298-99 (1967) (exigent circumstances and plain view).

${ }_{9}$ See, e.g., Groh, 540 U.S. at 561; Maryland v. Garrison, 480 U.S. 79, 84 (1987); Franks v. Delaware, 438 U.S. 154, 156 (1978).

${ }_{10}$ See United States v. Leon, 468 U.S. 897, 923 (1984) (describing four limited grounds on which defendant may later challenge search warrant); see also Franks, 438 U.S. at 156 (permitting defendant to challenge factual allegations in warrant affidavit only based on substantial showing of misrepresentation made intentionally, knowingly, or with reckless disregard for truth); DRESSLER, supra note 5, § 10.04[F] (discussing challenges based on scope of search authorized by warrant). 
validate the warrantless search. ${ }^{11}$ Certainly, the label of this doctrine as a "requirement" for search warrants overstates its scope; for this reason, describing it as a "preference" for warrants is probably more accurate. ${ }^{12}$

Whatever one's position on the persuasiveness of the various justifications for, and critiques of, the Court's warrant requirement jurisprudence, several fundamental points remain firmly grounded in the doctrine to this day.

First, the warrant requirement does not apply to any and all activities of the police in conducting a criminal investigation, but only to actions which constitute a "search" as defined by the Court in interpreting the scope of the Fourth Amendment. The Katz test provides that a "search" occurs when a "reasonable expectation of privacy" is breached by the police. ${ }^{13}$ Over the last half-century, nearly all of the Court's decisions determining which investigative techniques are or are not "searches" for purposes of the Fourth Amendment have applied and interpreted this doctrine. ${ }^{14}$ In 2012, however, the Court clarified in Jones $v$. United States that a "search" also occurs when the police physically intrude upon a constitutionally enumerated interest for the purpose of obtaining information. ${ }^{15}$ Although the outcomes created by the Jones trespass test and the Katz reasonable expectation of privacy test align in situations of physical entry or contact, ${ }^{16}$ the Katz test is broader because it imposes Fourth Amendment constraints in many scenarios falling outside the Jones test. ${ }^{17}$ So long as the Government has

11 See, e.g., United States v. Matlock, 415 U.S. 164, 177 \& n.14 (1974).

12 See, e.g., Maclin, supra note 6, at 203.

13 See generally DRESSLER, supra note 5, §§ 6.03-6.04. See also Katz v. United States, 389 U.S. 347,354 (1967).

${ }_{14}$ All of the pertinent "search" cases discussed in Parts II \& III, infra, address the application of the Katz test to the facts before the Court in one or more of the majority, concurring, or dissenting opinions. See infra Parts II \& III. The only case to discuss exclusively the Jones test, without citing or applying the Katz test, is the per curiam opinion in Grady v. North Carolina, 135 S. Ct. 1368, 1369-70 (2015) (holding that attachment of ankle bracelet for post-imprisonment satellite-based monitoring of sex offender constituted Fourth Amendment "search").

${ }_{15}$ See generally DRESSLER, supra note $5, \S 6.03[\mathrm{E}]$. See also Jones v. United States, 565 U.S. 400, 404, 406 n.3 (2012).

${ }_{16}$ See Florida v. Jardines, 569 U.S. 1, 5 (2013); id. at 13-14 (Kagan, J., concurring); Jones, 565 U.S. at 404-05; id. at 413 (Sotomayor, J., concurring); id. at 431 (Alito, J., concurring).

17 See, e.g., Carpenter v. United States, 138 S. Ct. 2206, 2211 (2018) (cellphone location information derived from carrier business records); Kyllo v. United States, 
performed a "search" under either test, though, Fourth Amendment rights-and the warrant requirement-will apply.

Second, the purpose of the warrant requirement is to facilitate judicial review of police investigative activity. ${ }^{18}$ As with the rest of constitutional law, separation of powers principles are an important safeguard against governmental overreach. ${ }^{19}$ In 1948, the Court in Johnson v. United States explained the applicability of judicial review to criminal procedure:

The point of the Fourth Amendment, which often is not grasped by zealous officers, is not that it denies law enforcement the support of the usual inferences which reasonable men draw from evidence. Its protection consists in requiring that those inferences be drawn by a neutral and detached magistrate instead of being judged by the officer engaged in the often competitive enterprise of ferreting out crime. ${ }^{20}$

Third, the framework created by the warrant requirement determines the timing of when this judicial review will occur. When the police obtain a search warrant, judicial review occurs in advance: by approving the application for a search warrant, the judge validates the search as "reasonable" before any intrusion into property or privacy takes place. ${ }^{21}$ When no warrant exists, judicial review necessarily occurs afterward, usually through a motion to suppress filed by the criminal defendant against whom the evidence would be used at trial. ${ }^{22}$ The Government might prevail against that motion in one of two

533 U.S. 27, 29 (2001) (thermal imager scan of home from street); Katz, 389 U.S at 348 (electronic eavesdropping using microphone attached to exterior of phone booth).

${ }_{18}$ See, e.g., Maclin, supra note 6, at 237-38; Benjamin J. Priester, Five Answers and Three Questions After United States v. Jones (2012), the Fourth Amendment “GPS Case," 65 OKLA. L. REV. 491, 512-16 (2013).

${ }_{19}$ See, e.g., Boumediene v. Bush, 553 U.S. 723, 742 (2008); Clinton v. City of New York, 524 U.S. 417, 450-53 (1998) (Kennedy, J., concurring).

${ }^{20}$ Johnson v. United States, 333 U.S. 11, 13-14 (1948).

${ }^{21}$ Only in a rare case would a defendant later prevail on a motion to suppress by arguing that the evidence seized pursuant to an executed search warrant is the product of a Fourth Amendment violation. See supra note 10. Claims relating to excessive force to persons or property by law enforcement in executing a valid warrant must be raised through civil litigation, see 42 U.S.C. $\$ 1983$ (2012), not under the exclusionary rule, see, e.g., Los Angeles County v. Rettele, 550 U.S. 609, 616 (2007) (per curiam).

${ }^{22}$ Challenges to warrantless searches under $\S 1983$ are infrequent, but they do occur. See, e.g., Valance v. Wisel, 110 F.3d 1269, 1272 (7th Cir. 1997) ("Valance appeals the district court's entry of summary judgment in favor of the six law enforcement officers he sued under 42 U.S.C. \$ 1983 ... [claiming they had] stopped his vehicle without probable cause and then detained him for the purpose of searching the vehicle." (footnote omitted)). 
situations: either because the investigation properly involved a "reasonable" warrantless search under a doctrinally recognized exception to the warrant requirement or because it did not involve a "search" subject to the Fourth Amendment's protections. ${ }^{23}$ Thus, by combining the significant benefits to the police from obtaining search warrants with the greater likelihood that evidence will be excluded from trial when they do not, the Court's doctrine intends to provide strong incentives for police to seek judicial review in advance, rather than after the fact, when conducting criminal investigations.

\section{B. The Conventional Wisdom}

Though, of course, the reality of the Court's opinions and the scholarly commentary is significantly more nuanced, the conventional wisdom about the warrant requirement and its history is fairly straightforward. Like any generalization, it has important inaccuracies, as well as a considerable element of truth at its core.

This conventional wisdom posits that the warrant requirement took hold and garnered its greatest force during the Warren Court and the early Burger Court in the 1960s and 1970 s, then suffered substantial undermining and retrenchment in the Rehnquist Court of the 1980s and 1990s, before reaching the contemporary Roberts Court shortly after the turn of the twenty-first century. ${ }^{24}$ The Court initially enforced the warrant requirement as the principal protection against unconstitutional searches, while the Court later placed more emphasis on the

${ }^{23}$ If the issue of whether a "search" of the defendant occurred is contested, the defendant has the burden of establishing that the Fourth Amendment's protections were triggered by the pertinent police activity. See Rakas v. Illinois, 439 U.S. 128, 130 n.1 (1978) ("The proponent of a motion to suppress has the burden of establishing that his own Fourth Amendment rights were violated by the challenged search or seizure."); see also Florida v. Riley, 488 U.S. 445, 455 (1989) (O'Connor, J., concurring) (" $[\mathrm{T}]$ he defendant must bear the burden of proving that ... a 'search' within the meaning of the Fourth Amendment even took place.").

${ }^{24}$ See, e.g., TINSLEY E. YARBOROUGH, THE REHNQUIST COURT AND THE CONSTITUTION 220-27 (2000); Akhil Reed Amar, The Future of Constitutional Criminal Procedure, 33 AM. CRIM. L. REv. 1123, 1125-27, 1131 (1996); Robert M. Bloom, Warrant Requirement - The Burger Court Approach, 53 U. CoLO. L. REV. 691 passim (1982); Maclin, supra note 6, at 198-202; Carol S. Steiker, CounterRevolution in Constitutional Criminal Procedure? Two Audiences, Two Answers, 94 MICH. L. REV. 2466, 2485-86 (1996); George C. Thomas III, Time Travel, Hovercrafts, and the Framers: James Madison Sees the Future and Rewrites the Fourth Amendment, 80 NOTRE DAME L. REV. 1451, 1457 (2005). John Roberts took office as Chief Justice in 2005. 
reasonableness requirement. ${ }^{25}$ As a consequence of this transformation in analytical approach, the Court showed its willingness to assess police investigations through a balancing of interests after the fact rather than relying on procedural hurdles in advance. ${ }^{26}$ The Warren Court's 1961 decision in Mapp v. Ohio made the Fourth Amendment exclusionary rule applicable not only in federal court, but also to state law enforcement investigations and criminal prosecutions. ${ }^{27}$ Beginning in 1984 with United States $v$. Leon and accelerating in recent years, later Courts introduced exceptions to the exclusionary rule to enable them to uphold convictions even when Fourth Amendment rights were violated. ${ }^{28}$ Similarly, the Warren Court's criminal procedure cases made extensive use of both direct appeal and habeas corpus to vindicate constitutional rights, while later Courts significantly reduced the availability of habeas corpus review, even before the 1996 statutory amendments. ${ }^{29}$ Fourth $^{2}$ Amendment cases followed the broader pattern in criminal procedure as a whole, with the Warren Court's rulings giving criminal defendants victory after victory while the Government frequently prevailed in the Rehnquist Court. ${ }^{30}$ Under this conventional wisdom, then, reliance on the warrant requirement

${ }^{25}$ See, e.g., Daniel J. Capra, Prisoners of Their Own Jurisprudence: Fourth and Fifth Amendment Cases in the Supreme Court, 36 VILL. L. REV. 1267, 1269-70, 1297 (1991); Maclin, supra note 6, at 198-202; Scott E. Sundby, A Return to Fourth Amendment Basics: Undoing the Mischief of Camara and Terry, 72 MINN. L. REV. 383, 386, 392-93 (1988); James F. Tomkovicz, California v. Acevedo: The Walls Close in on the Warrant Requirement, 29 AM. CRIM. L. REV. 1103, 1104 (1992).

${ }_{26}$ See, e.g., Thomas K. Clancy, The Fourth Amendment's Concept of Reasonableness, 2004 UTAH L. REV. 977, 1008-10 (2004); Wayne D. Holly, The Fourth Amendment Hangs in the Balance: Resurrecting the Warrant Requirement Through Strict Scrutiny, 13 N.Y.L. SCH. J. HUM. RTS. 531, 536-40 (1997); Maclin, supra note 6 , at $228-47$.

27367 U.S. $643,659-60$ (1961).

28468 U.S. 897, 923 (1984); see, e.g., Herring v. United States, 555 U.S. 135, 136-37 (2009); Hudson v. Michigan, 547 U.S. 586, 602 (2006); see also Collins v. Virginia, 138 S. Ct. 1663, 1675-80 (2018) (Thomas, J., concurring) (explaining "serious doubts" about constitutional basis for exclusionary rule and arguing that Court should revisit Mapp).

${ }^{29}$ Compare Fay v. Noia, 372 U.S. 391, 398-99 (1963), with Wainwright v. Sykes, 433 U.S. 72, 91 (1977); see also, e.g., McClesky v. Zant, 499 U.S. 467, 496-97 (1991); Teague v. Lane, 489 U.S. 288, 308, 310 (1989); Stone v. Powell, 428 U.S. 465, 493-94 (1976). Major amendments were enacted in the Antiterrorism and Effective Death Penalty Act of 1996 ("AEDPA"). See Pub. L. No. 104-132, 110 Stat. 1214 (codified at 28 U.S.C. \& 2254 (2012)).

${ }^{30}$ See generally YARBOROUGH, supra note 24 , at 215-42. 
as a means of protecting Fourth Amendment rights has been on the decline for nearly forty years.

In that regard, criminal procedure and the Fourth Amendment are little different than the broader span of constitutional law. As the Court in the later twentieth century shifted from consistent liberal majorities to consistent conservative ones, it was not unexpected that later decisions would reshape doctrinal principles governing search and seizure or Miranda rights ${ }^{31}$ as much as case law relating to unenumerated privacy rights, affirmative action, or economic regulation under the Commerce Clause. ${ }^{32}$ This mirrors the early twentieth-century shift from conservative majorities to liberal ones that led to contraction or repudiation of precedent on similar issues of national concern. ${ }^{33}$ At the same time, these high-level generalities are useful only as far as they go, and prominent counterexamples are not hard to find in criminal procedure as with any other doctrinal area. Most prominently, perhaps, the defendant-favorable Warren Court also decided Terry v. Ohio, promulgating the "stop and frisk" authority that is arguably the largest-and most abused-grant of discretion to police anywhere in Fourth Amendment case law. ${ }^{34}$

At a general level, the conventional wisdom has some utility as a rule of thumb in thinking about the path of the Court's decisionmaking. While overall trends in the doctrine might not predict the outcome of any particular case to reach the Court, they provide a sense of the norms and values guiding the Court's decisions. Ultimately, the conventional wisdom reflects the broad consensus from participants and observers about the aggregate direction taken by the Court over time.

31 See, e.g., Berghuis v. Thompkins, 560 U.S. 370, 389 (2010); United States v. Patane, 542 U.S. 630. 636-37 (2004); Oregon v. Elstad, 470 U.S. 298, 304 (1985); Rhode Island v. Innis, 446 U.S. 291, 302-03 (1980).

${ }^{32}$ See, e.g., Adarand Constructors, Inc. v. Pena, 515 U.S. 200, 227 (1995); United States v. Lopez, 514 U.S. 549, 567-68 (1995); Planned Parenthood v. Casey, 505 U.S. 833,874 (1992).

${ }^{33}$ See, e.g., Brown v. Board of Education, 347 U.S. 483, 495 (1954); West Coast Hotel v. Parrish, 300 U.S. 379, 400 (1937); Nebbia v. New York, 291 U.S. 502, 517 (1934); BARRY CUShMAN, RETHINKING THE NEW DeAL COURT: THE STRUCTURE OF A CONSTITUTIONAL REVOLUTION 3-7 (1998).

${ }^{34}$ See, e.g., Jeffrey Fagan, Terry's Original Sin, 2016 U. CHI. LEGAL F. 43, 66 (2016); David A. Harris, Factors for Reasonable Suspicion: When Black and Poor Means Stopped and Frisked, 69 IND. L.J. 659, 659-60, 677 (1994); Carol S. Steiker, Terry Unbound, 82 Miss. L.J. 329, 332-33 (2013). 
And that conventional wisdom suggests that the Roberts Court, building on the decisions of the Rehnquist Court that preceded it, would continue to limit the warrant requirement, to expand the reasonableness analysis, and to generally favor the Government rather than defendants in interpreting the scope of Fourth Amendment rights. Over the past decade, however, the Roberts Court has departed from this expectation in several significant ways. The unexpected resurgence of the warrant requirement in the Roberts Court deserves careful evaluation.

\section{THE WARRANT REQUIREMENT RESURGENCE}

The Fourth Amendment enumerates "persons, houses, papers, and effects" as the constitutionally protected interests secured "against unreasonable searches" carried out by the police or other governmental actors. ${ }^{35}$ Consequently, those interests long have served as the focus of the Court's analysis in interpreting the warrant requirement and related doctrinal principles. In the Roberts Court's decisions, these interests likewise have served as the primary-but not exclusive-source of the resurgence in the warrant requirement.

\section{A. Houses and Curtilage}

The principle that homes deserve an especially strong degree of protection against governmental intrusion has deep roots in the common law. ${ }^{36}$ The aphorism that a man's home is his castle reflects not only the preservation of property rights, including the power to exclude, but also the sanctity of the intimate details of private life held within. ${ }^{37}$ Even the much-ignored Third Amendment signifies the importance of keeping government agents out of private homes, except for the most justifiable of reasons. ${ }^{38}$ And this principle applies not only to the interior of

${ }^{35}$ U.S. CONST. amend. IV (1791). Like other areas of constitutional law, the Fourth Amendment only applies to state action, including informants or other individuals acting in cooperation with the police, but not to the actions of independent private parties. See, e.g., United States v. Jacobsen, 466 U.S. 109, 115 (1984) (private inspection followed by police search).

${ }^{36}$ See, e.g., Florida v. Jardines, 569 U.S. 1, 6-7 (2013); Kyllo v. United States, 533 U.S. 27, 31 (2001).

${ }_{37}$ See, e.g., Georgia v. Randolph, 547 U.S. 103, 115 (2006); Minnesota v. Carter, 525 U.S. 83, 94 (1998).

${ }^{38}$ See Katz v. United States, 389 U.S. 347, 350 n.5 (1967). 
the home contained within its walls but also to the outdoor curtilage immediately adjacent to the physical structure. ${ }^{39}$

It is fitting, then, that the Court has long insisted that a warrant is presumptively required to authorize constitutionally permissible police entry of a home. When the police have probable cause to arrest a suspect, they nevertheless must obtain an arrest warrant before entering his home to arrest him. ${ }^{40}$ Likewise, when the police have probable cause that evidence of crime is present in a residence, a search warrant-circumscribed by particularity as to the evidence expected to be discovered and seized-is required to authorize entry to obtain it. ${ }^{41}$ The Court's "knock and announce" decisions further protect the interests in property and privacy during the execution of warrants by requiring the police to give the resident an opportunity to admit the police by their own action and to avoid forcible entry. ${ }^{42}$ Thus, the heightened protection for the home is secured by requiring judicial review in advance of entry, helping to ensure that the intrusion by the police is sufficiently justified and limited.

Concomitantly, the Court has narrowly defined the situations in which that presumption can be overcome to justify a warrantless entry. Police acting in immediate "hot pursuit" of a felony suspect who flees into a home are not required to abandon their chase and to secure the scene from the outside while obtaining a warrant, thereby risking the suspect getting away or harming innocent persons inside. ${ }^{43}$ The same principle of impracticability authorizes warrantless entries of homes by the police acting as community caretakers, such as intervening to avoid potential harm by an individual who poses a danger to himself or to others ${ }^{44}$ or to prevent the imminent destruction of evidence that would be gone by the time the police would be able to make entry with a duly obtained warrant. ${ }^{45}$ Finally, the

${ }^{39}$ See, e.g., Jardines, 569 U.S. at 6-7.

40 See Payton v. New York, 445 U.S. 573, 586 (1980).

${ }^{41}$ See, e.g., Brigham City, Utah v. Stuart, 547 U.S. 398, 403 (2006); Groh v. Ramirez, 540 U.S. 551, 559 (2004); Kyllo, 533 U.S. at 31.

${ }^{42}$ See Hudson v. Michigan, 547 U.S. 586, 594 (2006); Richards v. Wisconsin, 520 U.S. 385, 387 (1997) (citing Wilson v. Arkansas, 514 U.S. 927, 934 (1995)).

${ }^{43}$ See United States v. Santana, 427 U.S. 38, 42-43 (1976); Warden, Md. Penitentiary v. Hayden, 387 U.S. 294, 298 (1967). But see Welsh v. Wisconsin, 466 U.S. 740, 754 (1984) (rejecting warrantless entry of home to pursue driver involved in misdemeanor traffic offense).

${ }^{44}$ See Michigan v. Fisher, 558 U.S. 45, 49 (2009) (per curiam); Stuart, 547 U.S. at $403-04$.

${ }_{45}^{4}$ See Kentucky v. King, 563 U.S. 452, 460, 460 n.3 (2011). 
requirement of a warrant to enter and search a home is overcome when a resident with common authority over the premises gives voluntary consent to the police, but only so long as that consent is neither withdrawn by that resident nor vitiated by another resident who is present and objects. ${ }^{46}$ When an entry is based on exigent circumstances or consent, the Court has determined that judicial review after the fact is adequate to preserve the resident's interests.

On the other hand, longstanding doctrine emphasizes an important distinction between physical entry to the home or curtilage and visual observation of those spaces from a lawful vantage point beyond the curtilage. An officer standing on the street or sidewalk, for example, might be able to see an object resting on a table on a front porch, to see the identifying features of a vehicle parked in an open garage, or to hear a loud noise emanating from behind a closed door or a shaded window. ${ }^{47}$ Such observations would not require a warrant because they do not constitute a "search" governed by the Fourth Amendment in the first instance. ${ }^{48}$ Thus, police may conduct such investigative activity on their own initiative, subject to judicial review afterward to confirm that the observations were performed in a permissible manner.

This lawful vantage point doctrine became the vector by which the Court confronted the use of technology to conduct observations of the home or curtilage. Although human beings are not capable of unassisted flight, the Court held in two cases decided in 1986 and 1989 that aerial observation of the curtilage from an airplane or helicopter qualified as a permissible warrantless observation from a lawful vantage point, including the use of an ordinary camera to take photographs of the property. ${ }^{49}$ No single line of reasoning garnered support from a

46 See Fernandez v. California, 571 U.S. 292, 298-301 (2014) (interpreting and applying Georgia v. Randolph, 547 U.S. 103, 107, 111, 122-23 (2006)); United States v. Matlock, 415 U.S. 164, 177-78 (1974)).

${ }_{47}$ Compare, e.g., Collins v. Virginia, 138 S. Ct. 1663, 1670-71 (2018); id. at 1681 (Alito, J., dissenting), and Florida v. Jardines, 569 U.S. 1, 6 (2013); id. at 13-15 (Kagan, J., concurring), with Kyllo v. United States, 533 U.S. 27, 43-44 (2001) (Stevens, J., dissenting).

${ }^{48}$ See, e.g., Kyllo, 533 U.S. at 32.

49 See Florida v. Riley, 488 U.S. 445, 448-49 (1989) (observation from helicopter at altitude of 400 feet with the naked eye); California v. Ciraolo, 476 U.S. 207, 209, 215 (1986) (observation from airplane at altitude of 1000 feet and photographs taken "with a standard $35 \mathrm{~mm}$ camera"). 
majority of the Court in these cases. ${ }^{50}$ The underlying analogy, however, is conceptually sound: areas of curtilage which might be obstructed from ground-level observation can be viewed by a variety of historically available unsophisticated methods, such as climbing a tree or perching atop the roof of a nearby building. Consequently, the police use of relatively mundane modern technology to obtain such views by aircraft is comparable enough to justify the same doctrinal result under the reasonable expectation of privacy analysis.

By contrast, the Court held in 1984 that the use of a radiotransmitter beeper to verify the presence of certain specific canisters of ether inside a particular residence could not be justified by this same reasoning. ${ }^{51}$ Rather, the use of the radio receiver from beyond the curtilage provided information the police could not otherwise have obtained from any lawful vantage point, and, thus, the police conducted a Fourth Amendment "search" by using the device to locate the canisters inside the home. ${ }^{52}$ In the absence of a warrant for that electronic surveillance of the contents of the home's interior, the search was an unconstitutional intrusion into the resident's reasonable expectation of privacy. ${ }^{53}$

In 2001, the Court in Kyllo v. United States confronted a far more advanced device deployed to investigate a home: a thermal imager displaying heat differentials-the kind of infrared vision previously available only to fictional superheroes and some nonhuman animal species. ${ }^{54}$ In defending the use of the imager by the police without first obtaining a warrant, the Government noted the agents' presence in a concededly lawful vantage point across the street from the home at the time they activated the device. ${ }^{55}$ But the Court rejected the significance of that viewing position and focused instead on the nature of the police interaction with the home. ${ }^{56}$ A breach of the resident's reasonable expectation of privacy occurred because the police made a constructive entry into the home by using senseenhancing technology to obtain information about the interior of

${ }^{50}$ Ciraolo was decided 5-4 and Riley was decided 4-1-4. See also Priester, supra note 18 , at 521 .

${ }^{51}$ United States v. Karo, 468 U.S. 705, 706 (1984).

${ }^{62}$ Id. at $714-16$.

${ }^{53}$ Id. at $717-18$.

${ }^{54}$ Kyllo v. United States, 533 U.S. 27, 29-30, 35-36, 36 n.3 (2001).

${ }^{55}$ Id. at $33-35 ; i d$. at 45,48 (Stevens, J., dissenting).

${ }^{56}$ Id. at 36-37, 40 (majority opinion). 
the home that otherwise could only have been known by physically entering the home. ${ }^{57}$ Justice Scalia's majority opinion emphasized that such a conclusion was necessary to ensure that homes retained the same degree of protection against governmental inspection as had been secured by the Framers in adopting the Fourth Amendment. ${ }^{58}$ At the same time, the opinion noted that if the sense-enhancing technology is in "general public use"-not further defined by the Kyllo Court-then a reasonable expectation of privacy is not breached; such observations would be anticipated, if not routine, in everyday life, whereas the use of nonpublic technology by the police constitutes an irregular or unusual observation of the home that residents cannot be deemed to have anticipated. ${ }^{59}$ Thus, Kyllo confirmed that the police do not need a warrant to make observations of a home or curtilage from a lawful vantage point using their ordinary senses or ordinary electronic devices-but once technological enhancement further expands the information available to the police, the constitutional calculus changes.

The Roberts Court has reaffirmed these core principles, enforcing the Fourth Amendment's protections against both physical and constructive entries to the home and curtilage. In doing so, the Court has protected the home and the curtilage against investigations that would be constitutionally permissible in public spaces, while laying the foundation for the important distinction between traditional physical inspections and technological surveillance that would guide its decisions beyond this limited context.

In 2013, the Court in Florida $v$. Jardines considered the implications of using a canine sniff from a trained drug-detection dog to determine the presence of illegal narcotics inside a home. ${ }^{60}$ Prior decisions in 1983 and 2005 had held that canine sniffs of airport luggage and of motor vehicles on public roadways did not constitute a "search" for Fourth Amendment purposes and thus could be performed as part of a preliminary police investigation without the need for any individual suspicion of the subject

\footnotetext{
${ }^{57} I d$. at $34,40$.

${ }_{58} I d$. at 31,34 .

69 See id. at 34, 40.

60 See Florida v. Jardines, 569 U.S. 1, 3-4 (2013).
} 
property, much less a search warrant. ${ }^{61}$ The Court based this rule primarily on the unique binary nature of the organic technology: a canine sniff can only determine the presence or the absence of contraband. ${ }^{62}$ In Jardines, the Government relied on that rationale to argue that the canine sniff of a home also should not constitute a "search" because it likewise would not reveal any private or intimate details of the home, just like the luggage or the car, but only the presence of contraband..$^{63}$ The Court rejected this argument, however, and held that a canine sniff of a home requires probable cause and a warrant. ${ }^{64}$ The majority opinion by Justice Scalia relied on the agent's physical entry into the curtilage-the agent and the dog stood on the home's front porch-for the purpose of enabling the dog to sniff from a position immediately adjacent to the front door, constituting a "search" under the terms of the Jones trespass test. ${ }^{65}$ The concurring opinion explained that the same result applied under the reasonable expectation of privacy test as elaborated in Kyllo, emphasizing that narcotics-detection dogs are not in "general public use"-and certainly not for the purpose of obtaining information about the interior contents of residences. ${ }^{66}$ Thus, although the Court's precedent gives the police considerable leeway to use canine sniffs to find drugs in public spaces, the heightened protection applicable to homes and curtilage supersedes this authority.

The 2018 decision in Collins $v$. Virginia reiterated this principle in the context of a physical search of a motorcycle. ${ }^{67}$ As discussed below, numerous prior cases had upheld warrantless searches of motor vehicles under the automobile exception to the warrant requirement, so long as the police had probable cause that evidence of crime was present. ${ }^{68}$ In Collins, the police located a motorcycle with probable cause to connect it to several prior incidents; an officer removed its tarp covering, photographed the motorcycle, and confirmed that its license plate

61 See Illinois v. Caballes, 543 U.S. 405, 410 (2005); United States v. Place, 462 U.S. 696, 707 (1983).

62 See Caballes, 543 U.S. at 409-10; Place, 462 U.S. at 707.

63 See Jardines, 569 U.S. 1 at 10.

64 Id. at $10-12$.

65 See id. at 5-10.

66 Id. at 11; see also id. at 14-15 (Kagan, J., concurring).

67 See Collins v. Virginia, 138 S. Ct. 1663, 1671 (2018).

68 See infra note 99 and accompanying text; see also Collins, $138 \mathrm{~S}$. Ct. at $1669-70$. 
and vehicle identification number matched a stolen vehicle. ${ }^{69}$ All of this would have been perfectly permissible under the automobile exception ${ }^{70}$-but when the officer performed the inspection, the motorcycle was parked in an open carport at the top of a driveway immediately adjacent to a home where the defendant possessed a reasonable expectation of privacy. ${ }^{71}$ As in Jardines, the Court in Collins held that the officer's physical intrusion into the home's curtilage for the purpose of obtaining information for the police investigation constituted a "search" for Fourth Amendment purposes. ${ }^{72}$ Consequently, even though the warrantless search of the vehicle itself would have been independently valid, the separate and distinct search of the curtilage was unconstitutional because it was not conducted pursuant to a search warrant.

The Court's controversial 2011 decision in Kentucky v. King authorized a warrantless physical entry into a home based on the exigent circumstances exception to the warrant requirement even in the context of a "police-created exigency" situation. ${ }^{73}$ In that case, the police had probable cause that illegal narcotics were present inside an apartment-but also believed that the individuals inside were unaware of either the officers' presence or the officers' knowledge. ${ }^{74}$ Based on those facts, Justice Ginsburg agreed with the defendant that exigent circumstances did not exist: the police had plenty of time to obtain a warrant before entering the apartment to search for and seize the drugs. ${ }^{75}$ Instead, however, the officers relied upon their longstanding "knock and talk" authority to pound on the apartment door, to declare their presence, and to seek cooperation from the residents. ${ }^{76}$ The individuals inside reacted by shouting and moving furniture, giving the officers additional probable cause:

69 Collins, 138 S.Ct. at 1668-69; see also id. at 1671 n.2; id. at 1681 (Alito, J., dissenting).

70 See id. at 1681-82 (Alito, J., dissenting).

71 See id. at 1670-71 (majority opinion). The state did not contest Collins' right to assert Fourth Amendment interests in the home because "[his] girlfriend lived in the house and ... Thel stayed there a few nights per week." Id. at 1668 \& n.1.

72 See id. at 1670-73. The officer "not only invaded Collins' Fourth Amendment interest in the item searched, i.e., the motorcycle, but also invaded Collins' Fourth Amendment interest in the curtilage of his home." Id. at 1671.

73 Kentucky v. King, 563 U.S. 452, 455, 461-62 (2011).

74 Id. at $455-57$.

75 Id. at 476-77 (Ginsburg, J., dissenting).

76 Id. at 456, 462 n.4, 472; see also Florida v. Jardines, 569 U.S. 1, 21-22 (2013) (Alito, J., dissenting) (describing "knock and talk" by police). 
the belief that the destruction of the drugs was imminent to avoid their discovery by the police. ${ }^{77}$ The eight-justice majority ruled that, on these facts, the exigent circumstances exception obviated the need for a warrant prior to entry of the apartment to secure the evidence before its disappearance. ${ }^{78}$ In essence, the Court determined that, although the police had created the opportunity for the exigency to arise, the existence of the exigency was entirely under the control of the individuals inside the apartment: had they simply remained calm in reaction to the provocative incitement of the "knock and talk," the officers would have been unable to assert a belief that any imminent destruction of evidence was probable. ${ }^{79}$ Viewed another way, although action by the police was a but-for cause of the exigency, its proximate cause was the reaction of the individuals inside. ${ }^{80}$ Just as the police may hope to rely on a resident's ignorance of his rights to obtain consent to search the premises ${ }^{81}$ so too the police may choose to take the calculated risk that revealing their presence may or may not induce a reaction that justifies immediate warrantless entry. Thus, although Kentucky v. King provides significant authority for warrantless entries to homes at the inducement of the police, the Court believed that its holding leaves control of the heightened Fourth Amendment protection for the home in the hands of the residents.

\section{B. Persons}

One might expect to see a long line of cases from the Court affirming that freedom from physical inspection or bodily intrusion of the person deserves equally strong protection as physical entry into the home or its curtilage and therefore enforcing the warrant requirement with significant rigor as to person as well as houses. Little such precedent exists, however-likely because the Government has rarely pressed a

${ }^{77}$ King, 563 U.S. at 456, 471-72.

78 See id. at $469-72$.

79 See id. at $457-58$.

80 "Occupants who choose not to stand on their constitutional rights but instead elect to attempt to destroy evidence have only themselves to blame for the warrantless exigent-circumstances search that may ensue." Id. at 470.

81 See United States v. Drayton, 536 U.S. 194, 199-201 (2002) (consent to search of person and luggage on passenger bus); Ohio v. Robinette, 519 U.S. 33, 35 (1996) (consent to search of automobile). 
contrary argument in a criminal case in a manner that could reach the Court on discretionary review. ${ }^{82}$

Instead, the Court's cases establish a variety of scenarios in which the police are uncontestably performing a "search" of the person, but where that search is constitutionally reasonable without a warrant. When an individual has been lawfully arrested with probable cause, the arresting officer may inspect the person, his clothing, and any containers or objects found on him. ${ }^{83}$ This immediate, warrantless search is justified by the twin interests of protecting the officer from possible ambush by concealed weapons or dangerous items and securing any destructible evidence in the arrestee's possession-and by the principle of impracticability, because those interests would be thwarted by the delay attendant to obtaining a search warrant. ${ }^{84}$ Similarly, the exterior pat down of clothing carried out as part of a Terry stop-and-frisk protects the officer from potential attack by an armed and dangerous individual during a temporary investigative detention that is even shorter in duration and less secure than a custodial arrest, making warrants even more impracticable in that context. ${ }^{85}$ Even in the more controlled setting of the police station, certain warrantless searches of the person are reasonable. If the arrestee is to be held in custody in jail, a full-body strip search of the person is permissible before introduction into the inmate population. ${ }^{86} \mathrm{~A}$ cotton swab may be

${ }^{82}$ For example, in Grady v. North Carolina, the Court addressed the use of an ankle bracelet GPS tracking device to monitor the location of a recidivist sex offender after release from incarceration, but only for the limited purpose of confirming that such a post-conviction program constitutes a "search" subject to Fourth Amendment analysis even when it is civil in nature. See $135 \mathrm{~S}$. Ct. 1368, 1370-71 (2015) (per curiam). The Court has ruled that certain searches of the person violate the Fourth Amendment in $\S 1983$ cases as well. See, e.g., Safford Unified Sch. Dist. v. Redding, 557 U.S. 364, 368, 378-79 (2009) (holding that, notwithstanding school officials' extensive authority and discretion, a strip search of a middle school student suspected of possessing and distributing ibuprofen in violation of school rules was an unreasonable violation of the Fourth Amendment); Ferguson v, City of Charleston, 532 U.S. 67, 79-86 (2001) (holding that involuntary drug testing of pregnant mothers in a public hospital did not qualify as a "special needs" search and thus was an unreasonable violation of the Fourth Amendment without a warrant and probable cause).

${ }_{83}$ See United States v. Robinson, 414 U.S. 218, 235 (1973).

84 See Arizona v. Gant, 556 U.S. 332, 338-39 (2009).

85 See Terry v. Ohio, 392 U.S. 1, 20, 23-31 (1968); see also, e.g., Minnesota v. Dickerson, 508 U.S. 366, 378 (1993) (applying limited scope of permissible Terry frisk).

${ }^{86}$ See Florence v. Bd. of Chosen Freeholders of Burlington, 566 U.S. 318, 334, $338-39$ (2012). 
inserted into the mouth to obtain a saliva sample for DNA identification purposes ${ }^{87}$ and a DUI arrestee may be compelled to exhale air into a breathalyzer device to confirm blood-alcohol content ("BAC"). ${ }^{88}$ In each of these situations, the Court is satisfied with judicial review of the bodily search after the fact in a motion to suppress.

Yet, the Roberts Court has found occasion to reinvigorate the warrant requirement for searches of the person in light of recent technological advancements. In 1966, the Court held in Schmerber $v$. California that a police officer could obtain a warrantless blood draw by a medical professional to establish $\mathrm{BAC}$ in a drunk driving investigation, reasoning that the reliability of the BAC calculation would be compromised by the delay caused by waiting for a search warrant, thereby creating exigent circumstances to secure the evidence immediately before its degradation. ${ }^{89}$ Relying on this decision, some states statutorily authorized police to obtain compelled blood draws from DUI arrestees. ${ }^{90}$ In a pair of decisions in 2013 and 2016, the Court ruled these statutes unconstitutional as applied to most DUI arrests and sharply narrowed the exigency rationale for DUI blood draws. ${ }^{91}$ The Court repudiated neither the scientific rationale-it remains true today that the body's natural metabolism degrades BAC over time-nor the inherent presence of probable cause to justify confirming BAC that comes with any lawful drunk driving arrest. ${ }^{92}$ Instead, the Court emphasized that the processing time in obtaining warrants has decreased substantially over the half-century since Schmerber, mooting the exigency concerns under most circumstances. ${ }^{93}$

In particular, the Court reasoned in both Missouri $v$. McNeely and Birchfield $v$. North Dakota that today's readily available technology means that it is no longer necessary for either an officer to physically visit the courthouse to file tangible paperwork or a judge to be physically present in the courthouse building to review it for a search warrant to be issued. ${ }^{94}$ Rules of

${ }^{87}$ See Maryland v. King, 569 U.S. 435, 465-66 (2013).

88 See Birchfield v. North Dakota, 136 S. Ct. 2160, 2176-78, 2184-85 (2016).

89384 U.S. 757, 770-72 (1966).

90 See Missouri v. McNeely, 569 U.S. 141, 160-61 (2013).

${ }_{91}$ Birchfield, 136 S. Ct. at 2185-86; McNeely, 569 U.S. at 160-63, 165.

92 See Birchfield, 136 S. Ct. at 2174; McNeely, 569 U.S. at 151-52.

93 See McNeely, 569 U.S. at 154-55.

94 See Birchfield, 136 S. Ct. at 2192-93 (Sotomayor, J., concurring in part and dissenting in part); McNeely, 569 U.S. at 154-55. 
procedure have been amended to allow police officers to submit warrant applications electronically from the field, such as from Wi-Fi-enabled laptops in patrol cars, and for judges to approve them electronically in a matter of minutes, including from a home computer-or perhaps even a smartphone. ${ }^{95}$ This ready availability of electronic warrants has dramatically reduced the delay involved in waiting to obtain judicial review in advance of the search; a process that might have taken hours now can occur in a matter of minutes, especially if an on-call judge is assigned to review electronic requests promptly at any hour of the day or night. ${ }^{96}$ Accordingly, the Court refused to allow statutory authority to remain premised on obsolete assessments of delay and exigency, holding that a warrantless DUI blood draw to confirm BAC is constitutionally permissible only based on a fact-specific showing of impracticability in obtaining an electronic warrant expeditiously in the context of a particular arrest..$^{97}$ Although the search of the person involved in McNeely and Birchfield is an especially intrusive one-a medical procedure to pierce the skin and withdraw blood-the Court's reasoning about the speed at which warrants can now be obtained has the potential to resonate in the analysis of any exception to the warrant requirement based on principles of impracticability.

\section{Effects}

The recognized exceptions to the warrant requirement authorize a wide variety of warrantless searches of personal effects. Searches incident to arrest encompass not only the warrantless seizure of physical objects found on the person, but also subsequent warrantless inspection to determine what has been found, such as laboratory testing to confirm the presence of illegal narcotics. ${ }^{98}$ When the police have probable cause, the automobile exception similarly permits both the warrantless seizure of a motor vehicle and the warrantless search of

${ }_{95}$ See McNeely, 569 U.S. at 154-55.

${ }_{96}$ See McNeely, 569 U.S. at $154-55,164$.

${ }_{97}$ See Birchfield, $136 \mathrm{~S}$. Ct. at 2184, 2186; McNeely, 569 U.S. at 156, 164. The dissent in Birchfield argued that the same reasoning should require a search warrant for a BAC breath test as well. See $136 \mathrm{~S}$. Ct. at 2195-96 (Sotomayor, J., concurring in part and dissenting in part).

${ }_{98}$ See, e.g., Arizona v. Gant, 556 U.S. 332, 336 (2009) (bag of cocaine found in pocket of jacket in back seat of car after driver's arrest for traffic offense); United States v. Robinson, 414 U.S. 218, 222-23 (1973) (heroin capsules found in cigarette carton in shirt pocket of driver arrested for traffic offense). 
anywhere within the vehicle where the evidence sought could be found, including storage spaces in the car like the trunk or glove compartment, as well as personal effects found inside the car, such as a purse or bag. ${ }^{99}$ Personal property in police custody arriving at the police station, such as during booking of an arrestee or impoundment of a car, is subject to an inventory search using the department's established standardized protocols. ${ }^{100}$ And a person may give voluntary consent to allow the police to inspect his property even if the police can articulate no individualized suspicion for requesting cooperation from him. ${ }^{101}$ Thus, tangible personal property as a category receives less rigorous Fourth Amendment protection than homes or persons. ${ }^{102}$

On the other hand, authority to search personal effects is not unrestricted, and the police must take care to ensure that a valid exception to the warrant requirement applies. In 1977, the Court considered the somewhat remarkable facts of United States $v$. Chadwick. ${ }^{103}$ FBI agents had clear probable cause from a canine sniff that the defendants' footlocker contained illegal narcotics; after the defendants loaded the footlocker into the trunk of a car but before they drove away, the agents arrested them and seized the footlocker, which was opened several hours later at the FBI office without a warrant. ${ }^{104}$ The Court explained why, on the facts, the agents could not rely upon exigent circumstances, the automobile exception, search incident to arrest, inventory search, or consent to overcome the need for a search warrant-and, therefore, the marijuana inside the footlocker had been found in violation of the Fourth Amendment. ${ }^{105}$ The 2000 decision in Bond $v$. United States reaffirmed this principle. ${ }^{106}$ While lawfully interacting with bus passengers at a valid immigration checkpoint near the border with Mexico, an agent reached up to

99 See Wyoming v. Houghton, 526 U.S. 295, 298 (1999) (purse on back seat); see also California v. Acevedo, 500 U.S. 565, 567 (1991) (paper bag in trunk).

100 See Florida v. Wells, 495 U.S. 1, 4 (1990); see also Illinois v. Lafayette, 462 U.S. 640, 648 (1983); South Dakota v. Opperman, 428 U.S. 364, 369 (1976).

101 See, e.g., United States v. Drayton, 536 U.S. 194, 200-01 (2002).

102 Where the nature of an object as a dangerous weapon or criminal evidence is "immediately apparent," the police may seize it on the spot without a warrant to secure its later use against the individual. See, e.g., Minnesota v. Dickerson, 508 U.S. 366, 375 (1993); Horton v. California, 496 U.S. 128, 136-37 (1990).

103433 U.S. $1,3-5$ (1977).

${ }_{104}$ Id.

105 See id. at 5-6, 11, 13, 14-15.

106529 U.S. 334, 338-39 (2000). 
the overhead storage space and squeezed a soft-sided duffel bag belonging to the defendant. ${ }^{107}$ The Court rejected the Government's position that the agent's action was routine, incidental contact, which the defendant necessarily accepted while traveling on a passenger bus and instead ruled that the agent's exploratory manipulation of the bag exceeded the permissible bounds of interaction between fellow travelers and therefore breached his reasonable expectation of privacy on the facts without any applicable exception to the warrant requirement. ${ }^{108}$

The Jones decision in 2012 extended this principle, holding that a physical trespass upon the defendant's motor vehicle for the purpose of obtaining information-specifically, the attachment of a GPS device which electronically transmitted its coordinates at frequent intervals to create an ongoing log of its location-constituted a search of the vehicle requiring a warrant. ${ }^{109}$ The majority opinion reached this conclusion even though the information ultimately sought by the Government involved electronic data points about the vehicle's public movements over time rather than the nature of its physical contents, unlike the interior inspections of containers in Chadwick and Bond or the canine sniff of the automobile in Illinois $v$. Caballes. ${ }^{110}$ One important limitation governs the Fourth Amendment protection of effects: the challenged search must relate to the defendant's own personal effects. For example, discarded or abandoned property no longer carries any reasonable expectation of privacy, so a defendant could not claim Fourth Amendment protection against police inspection of his curbside trash left out for pickup. ${ }^{111}$ Similarly, the Court held that a temporary passenger in a car cannot assert a reasonable expectation of privacy against police search of the vehicle unless the individual can establish some ownership or possessory

${ }^{107} I d$. at $335-36$.

$108 \mathrm{Id}$. at $338-39$.

${ }^{109}$ See United States v. Jones, 565 U.S. 400, 404-05 (2012). The Government had obtained a warrant but failed to execute it in compliance with its terms; for the purposes of its decision, the Court treated the case as involving warrantless GPS surveillance. Id. at 402-03, $403 \mathrm{n} .1$.

${ }_{110} I d$. at 408-09; see also id. at 430-31 (Alito, J., concurring) (reaching same conclusion under Katz test).

${ }^{111}$ See California v. Greenwood, 486 U.S. 35, 40 (1988). 
interest in either the vehicle itself or the items discovered during the search. ${ }^{112}$

The 2018 decision in Byrd $v$. United States, however, indicates that the Roberts Court follows a functional approach to this doctrine rather than a formalistic one. ${ }^{113}$ In that case, the defendant's acquaintance obtained a rental car on his behalf, apparently because he knew that his criminal record would cause him to be rejected, and the defendant's driving of the vehicle indisputably violated the terms of the rental contract as executed by the acquaintance. ${ }^{114}$ The Government claimed that the defendant therefore lacked any reasonable expectation of privacy in the vehicle and could not object to the search of the trunk that uncovered body armor and a considerable quantity of illegal narcotics, but the Court unanimously rejected that argument. ${ }^{115}$ Instead, the Court ruled that the breach of contract alone was insufficient to abrogate the defendant's Fourth Amendment rights, particularly because his right to possess, control, and exclude others from the car was nevertheless superior to anyone else's. ${ }^{116}$ Although the Court remanded for a determination of whether the search might be upheld on some other basis, the emphasis on a pragmatic rather than technical interpretation of the definition of "his" effects for Fourth Amendment purposes is doctrinally significant. ${ }^{117}$

${ }_{112}$ See Rakas v. Illinois, 439 U.S. 128, 148 (1978). In Rakas, the defendants disclaimed ownership of the items seized as evidence, which were later connected to them anyway. Id. at 130-31, 148. In Wyoming $v$. Houghton, by contrast, a car passenger undeniably had a reasonable expectation of privacy in her own purse, but the warrantless search of her purse was constitutional as part of an overall search of the car under the automobile exception. 526 U.S. 295, 298, 300, 307 (1999). The Court has recognized that guests in homes possess broader reasonable expectation of privacy interests. See Minnesota v. Carter, 525 U.S. 83, 89 (1998); Minnesota v. Olson, 495 U.S. 91, 98-99 (1990).

113138 S. Ct. 1518, 1530-31 (2018).

114 Id. at 1524, 1529-30.

115 Id. at 1525, 1527; see also id. at 1531 (Thomas, J., concurring); id. at 1531-32 (Alito, J., concurring).

${ }^{116}$ Id. at 1527-29 (majority opinion).

117 See id. at 1526-27, 1530; see also id. at 1531 (Thomas, J., concurring). The Court noted that, on remand, the lower courts could consider whether on these facts the defendant should be treated as equivalent to a wrongful possessor like a thief, as well as whether the police had probable cause to lawfully search the car without a warrant in any event under the automobile exception. See id. at 1529-31 (majority opinion); id. at 1532 (Alito, J., concurring). 


\section{Papers}

The protection against unreasonable searches or seizures of papers has the same limitation: only the person whose papers were seized or searched has a Fourth Amendment interest to assert. Under the "third party doctrine" component of the Katz analysis, an individual has no reasonable expectation of privacy in business records created or maintained by companies with which they interact. ${ }^{118}$ Thus, no "search" for Fourth Amendment purposes occurs, and neither individualized suspicion nor a warrant is required, when the police obtain bank records, phone company dialing records, or billing records relating to a customer. ${ }^{119}$ Even in a case where agents acting without a warrant brazenly absconded with a bank vice president's briefcase and successfully copied the papers inside before he returned from dinner none the wiser, the Court held that the bank customer whose records had been obtained in the raid nevertheless could not suppress those papers from his criminal trial, because only the vice president's Fourth Amendment rights had been violated, not the customer's own personal rights. ${ }^{120}$

In some cases, of course, the defendant's own papers will be at issue. As with bodily searches of persons, the Court has few contemporary decisions in which the importance of the Fourth Amendment warrant requirement to inspections of papers by the police is a noteworthy aspect of a doctrinal holding. ${ }^{121}$ As with searches of effects, recognized exceptions to the warrant requirement provide a number of contexts in which the police would incidentally acquire, and observe the contents of, various writings, such as the exterior notation on an envelope discovered in plain view during a search of a car or a handwritten list found

118 See Priester, supra note 18, at 525-26.

119 See Smith v. Maryland, 442 U.S. 735, 745-46 (1979) (phone company dialing records for individual customer); United States v. Miller, 425 U.S. 435,446 (1976) (bank account records for individual customer); Cal. Bankers Ass'n v. Shultz, 416 U.S. 21, 52-54 (1974) (bank business records required pursuant to Bank Secrecy Act).

120 United States v. Payner, 447 U.S. 727, 735 (1980).

${ }_{121}$ The Court has addressed governmental investigation into papers more frequently under the Fifth Amendment privilege against self-incrimination. See, e.g., United States v. Hubbell, 530 U.S. 27, 29-30, 34 (2000) (grand jury subpoena for business records also implicating personal criminal liability of recipient); United States v. Doe, 465 U.S. 605, 606-07 (1984) (grand jury subpoena for sole proprietorship business records); Fisher v. United States, 425 U.S. 391, 394, 396 (1976) (IRS summons for taxpayer documents); see also infra note 195 (discussing Fourth Amendment implications for subpoenas after Carpenter). 
in the pocket of an arrestee. ${ }^{122}$ On the other hand, when the police specifically set out to locate and take custody of a person's documents with the objective of performing a thorough evidentiary search for written evidence of crime contained therein, the Court presumably has assumed that the police and the lower courts understood that a search warrant is required both to seize and to read and analyze such papers as part of a police investigation. ${ }^{123}$

For that reason, the Court's 2014 decision in Riley $v$. California is profoundly significant in declaring that the warrant requirement applies to evidentiary searches of digital data contained on electronic devices the police have lawfully seized. ${ }^{124}$ The defendants in Riley had been lawfully arrested and brought to the police station, where the police had lawful custody of the smartphones removed from their persons incident to the arrests. ${ }^{125}$ Without obtaining search warrants, the police conducted inspections of the digital data on the phonesincluding phone numbers, contacts lists, text messages, and photographs - which resulted in the discovery of evidence used to convict the defendants. ${ }^{126}$ The Government sought to defend the inspections as a valid warrantless search incident to arrest; although the Court agreed that inspection of physical objects found on the person should remain permissible, it rejected the applicability of that exception to the warrant requirement for digital data. ${ }^{127}$ Accordingly, the Court overturned the convictions, ruling that the evidence obtained from the

${ }^{122}$ See, e.g., New York v. Belton, 453 U.S. 454, 455-56 (1980) (stating that an officer conducting traffic stop observed "on the floor of the car an envelope marked 'Supergold' that he associated with marihuana" and, after arresting the car's occupants, "picked up the envelope marked 'Supergold' and found that it contained marihuana"). "It has long been accepted that written items found on the person of an arrestee may be examined and used at trial.” Riley v. California, 573 U.S. 373, 405 \& n.* (2014) (Alito, J., concurring) (citing authorities).

${ }^{123}$ Different principles apply when government investigators seek to inspect papers for administrative or regulatory purposes, rather than as part of a criminal investigation. See, e.g., City of Los Angeles v. Patel, 135 S. Ct. 2443, 2452 (2015). Grand jury subpoenas have also traditionally been subject to different Fourth Amendment analysis than investigative action by the police has been. See infra note 195.

${ }^{124}$ See 573 U.S. $373,403$.

125 See id. at 378-81.

126 See id.

127 See id. at 386. 
warrantless search of the phones' digital data should have been suppressed under the exclusionary rule. ${ }^{128}$

Most importantly, the Riley Court emphasized that the digital data contained on electronic devices is both quantitatively and qualitatively different than information revealed by physical objects, including traditional papers. ${ }^{129}$ The vast data-storage capacities of today's handheld devices-not to mention information stored in "the cloud" and equally accessible from an internet-enabled device-is orders of magnitude larger than what any person could have physically carried with them in a purse, briefcase, or even a duffel bag or rolling luggage. ${ }^{130}$ Likewise, much of this data is highly personal in nature-from medical information and religious or political affiliation to intensely private intimate details of a person's life-and was never carried around as a matter of course in everyday life in earlier times. ${ }^{131}$ Taken together, the information revealed by an evidentiary search of digital data on smartphones and similar devices simply is not analogous to the inspection of physical objects. ${ }^{132}$ Thus, the Court recognized that doctrinal principles grounded in the practical realities of the common law, and even the analog modern period, cannot be transposed by rote to digital data in the internet age.

\section{E. "Surveillance" in the Analog Age: Eavesdropping and Location Tracking}

From the ratification of the Constitution to today, federal criminal law enforcement has always been a small fraction of the overall criminal justice system in the United States, even during the heights of alcohol Prohibition in the 1920s and the "war on drugs" in the 1980s. ${ }^{133}$ Consequently, prior to Mapp in 1961, the

${ }^{128}$ See id. at 403 . For one defendant, the Court affirmed the reversal of the conviction by the lower court. See id.

129 See id. at 393-94.

130 See id. at 393-95.

131 See id. at $395-97$.

${ }_{132}$ See id. at $386,397$.

${ }_{133}$ Compare Total Incoming Criminal Caseloads Reported by State Courts, All States, 2007-2016, COURT STATISTICS PROJECT, http://www.courtstatistics.org/ / media/Microsites/Files/CSP/Criminal/PDFs/EWSC-2016-CRIM-Page-1-Trend.ashx (last visited May 16, 2019) (reporting 17.8 million incoming state criminal cases in 2016), with Federal Judicial Caseload Statistics 2016, UNITED STATES CoURTS, https://www.uscourts.gov/statistics-reports/federal-judicial-caseload-statistics-2016 (last visited May 16, 2019) (reporting 79,787 filings for criminal defendants in federal district courts in 2016). 
Court had decided a comparatively small number of constitutional criminal procedure cases, although some contemporary doctrines have their roots in that period. ${ }^{134}$ After the incorporation of the Fourth Amendment and the exclusionary rule to the states, though, the Court began to review investigations conducted not only by highly trained and well-funded federal agencies like the FBI, but also all manner of state and local law enforcement around the country, including some plagued by incompetence, vindictiveness, or racism in addition to less sophistication in best practices or legal obligations. ${ }^{135}$ It is not surprising, then, that this exposure to the reality of law enforcement in the United States led the Court to seek to ensure judicial review of a broader scope of police investigations than it historically had required.

One vector in this transformation occurred in the Court's definition of what kinds of police surveillance activity constitute a "search" for Fourth Amendment purposes. Until the mid-twentieth century, the police necessarily conducted investigations by using their natural senses to make observations of physical places and tangible evidence because little else was technologically possible. When police began to make use of electronic eavesdropping, such as microphones and wiretaps, to investigate suspects, the Court initially retained its existing doctrine, holding that no "search" occurred unless the police physically entered a constitutionally protected area such as a home or office. ${ }^{136}$ For example, the Court held that police needed probable cause and a warrant to deploy a "spike mike" that physically penetrated into a wall of a house, but not to install a wiretap that intruded into a phone line at a position on the street where the homeowner had no property interest in the phone company's hardware. ${ }^{137}$ The scope of an individual's Fourth

134 See generally, e.g., Marron v. United States, 275 U.S. 192 (1927) (warrantless search incident to arrest); Carroll v. United States, 267 U.S. 132 (1925) (warrantless searches of automobiles); Weeks v. United States, 232 U.S. 383 (1914) (exclusionary rule).

135 See generally, e.g., Blackledge v. Perry, 417 U.S. 21 (1974); Cox v. Louisiana, 379 U.S. 536 (1965); Escobedo v. Illinois, 378 U.S. 478 (1964).

${ }^{136}$ See Katz v. United States, 389 U.S. 347, 351-53 (1967).

${ }_{137}$ See Silverman v. United States, 365 U.S. 505, 506-07, 511-12 (1961) (spike mike physically intruding into a "constitutionally protected area"); id. at 508-10 (distinguishing Goldman v. United States, 316 U.S. 129 (1942), which involved a "detectaphone" placed flush against a wall without physically penetrating into it); Olmstead v. United States, 277 U.S. 438, 456-57 (1928) (wiretap into home phone lines on street outside). 
Amendment rights depended on the specific type of technology used by the police in a particular instance, rather than on the kind of evidence the police hoped to acquire.

In 1967, the Court in Katz rejected this narrow interpretation of the Fourth Amendment. ${ }^{138}$ Famously, the Court declared that "the Fourth Amendment protects people, not places," and ruled that the Fourth Amendment applied to the use of an eavesdropping microphone affixed to the exterior of a glass phone booth to perform surveillance on the occupant's end of the phone conversation. ${ }^{139}$ Rather than restrict the scope of the Fourth Amendment to physical intrusions into houses or physical inspections of tangible effects or papers, the Court recognized that technological surveillance poses an equally great threat to liberty and privacy. ${ }^{140}$ After all, eavesdropping or wiretapping a phone call may be just as valuable to the police as reading a person's written papers, or a recording of a conversation just as powerful evidence of guilt in court as revealing a written document planning or confessing the crime. Accordingly, the Court adopted a doctrinal test based on the exercise of reasoned normative judgment about which police investigative techniques should be subject to advance judicial review. ${ }^{141}$

Importantly, the Court's doctrinal shift in Katz did not make the Fourth Amendment concept of a "search" coextensive with the existence of a police investigation for information or evidence. ${ }^{142}$ For example, after Katz the Court reaffirmed the "open fields" doctrine, which provides Fourth Amendment

138 See Katz, 389 U.S. at 353.

139 See id. at 351 ; see also id. at 359.

140 See id. at $355-58$.

141 See, e.g., Carpenter v. United States, 138 S. Ct. 2206, 2246 (2018) (Thomas, $\mathrm{J}$., dissenting) (" $[\mathrm{A}]$ normative understanding is the only way to make sense of this Court's precedents .... .); Nicholas Kahn-Fogel, An Examination of the Coherence of Fourth Amendment Jurisprudence, 26 CORNELL J.L. \& PUB. POL'Y 275, 283 \& n.38, 39 (2016); Orin S. Kerr, Katz Has Only One Step: The Irrelevance of Subjective Expectations, 82 U. CHI. L. REV. 113, 115, 132, 134 (2015); Orin S. Kerr, Four Models of Fourth Amendment Protection, 60 STAN. L. REV. 503, 520 (2007); Matthew B. Kugler \& Lior Jacob Strahilevitz, The Myth of Fourth Amendment Circularity, $84 \mathrm{U}$. CHI. L. REV. 1747, 1754 (2017); Anna Lvovsky, Fourth Amendment Moralism, 166 U. PA. L. REV. 1189, 1209 (2018); Matthew Tokson, Knowledge and Fourth Amendment Privacy, 111 NW. U. L. REv. 139, 194 (2016).

${ }_{142}$ But see Carpenter, $138 \mathrm{~S}$. Ct. at 2238 (Thomas, J., dissenting) (noting that the term "search" was not a term of art at the time of the Founding); see also Brief of Scholars of the History and Original Meaning of the Fourth Amendment as Amici Curiae in Support of Petitioner at 6-14, Carpenter v. United States, 138 S. Ct. 2206 (2018) (No. 16-402) [hereinafter Historical Scholars Brief]. 
protection for homes and curtilage but not for other real property owned by an individual. ${ }^{143}$ Fences and "no trespassing" signs are insufficient, the Court determined, to meaningfully prevent others-whether the public at large or the police-from crossing rural land to observe marijuana growing in a wooded area over a mile away from a home or to peer inside a barn housing an amphetamine lab rather than horses or cattle. ${ }^{144}$ While the individual landowners surely did not anticipate the police discovery of their crimes in that manner, the Court ruled that no reasonable expectation of privacy was breached by the police physically crossing land and visually inspecting plants or structures found in a location qualifying as open fields. ${ }^{145}$

Similarly, the Court did not determine that all forms of technologically enhanced police investigation, simply by the fact of that enhancement, justified the reliance on the warrant requirement for oversight and accountability. The Katz decision itself noted that information which a person "knowingly exposes to the public" lacks constitutional protection from police discovery. ${ }^{146} \mathrm{Katz}$ distinguished the agents' electronic eavesdropping on the contents of the defendant's spoken words, which the phone booth kept obscured from being overheard by the naked ear, and their visual observation of his presence through the transparent glass, which the defendant accepted as a necessary consequence of making the phone call on the street rather than inside a building. ${ }^{147}$

In 1983, the Court applied this rationale in United States $v$. Knotts to conclude that a person cannot claim a reasonable expectation of privacy against observation of his movements on public roads. ${ }^{148}$ Standing alone, police officers in an unmarked car "tailing" a motor vehicle to track its location by following its travels and keeping it in sight without revealing their presence was not constitutionally distinguishable from constables attempting to surreptitiously follow a person traveling on foot or

${ }^{143}$ See United States v. Dunn, 480 U.S. 294, 294 (1987); Oliver v. United States, 466 U.S. 170, 181 (1984); Hester v. United States, 265 U.S. 57, 59 (1924).

144 See Dunn, 480 U.S. at 297-300; Oliver, 466 U.S. at 173-74.

145 See Dunn, 480 U.S. at 300-04; Oliver, 466 U.S. at 179-81, 182.

146 See Katz v. United States, 389 U.S. 347, 351 (1967).

147 See id. at 352 . "But what he sought to exclude when he entered the booth was not the intruding eye-it was the uninvited ear." Id.

148 United States v. Knotts, 460 U.S. 276, 281-82 (1983). 
horseback in earlier times. ${ }^{149}$ In Knotts, however, the police conducting visual observation using a pursuing car and overhead helicopter supplemented their tracking by means of a radio-transmitter beeper that emitted an intermittent pulse detectable by an attuned receiver in the helicopter. ${ }^{150}$ The defendant argued that this technologically enhanced surveillance of the car's drive from Minneapolis, Minnesota, to a cabin in western Wisconsin required different treatment under Katz. ${ }^{151}$ The Court rejected that claim and held that the use of the beeper to minimize the opportunity for error in tracking the defendant's location on public roads did not breach a reasonable expectation of privacy, and thus no warrant was required..$^{152}$

Although the Court in 2012 unanimously ruled in Jones that the month-long warrantless GPS tracking of the defendant's vehicle violated his Fourth Amendment rights, the Court's reasoning in doing so reaffirmed the surveillance analysis under $\mathrm{Katz}$ in contexts more closely resembling its original analog-era incarnation. ${ }^{153}$ The majority opinion's trespass test analysis has no applicability in situations like Knotts, where the surveillance involved only observation from afar. ${ }^{154}$ Likewise, the Jones concurring opinion's Katz analysis specifically emphasized that short-term location tracking breaches no reasonable expectation of privacy because it is a longstanding routine police practice that consumes relatively few police resources. ${ }^{155}$ What distinguished Jones from Knotts in the Katz analysis was both the quantity of location tracking data gathered by the electronically enhanced surveillance-not simply for twenty-eight days, but twenty-four hours per day to accumulate over two thousand pages of location data points-and the qualitative nature of the technology involved-using automated hardware and software to generate surveillance data with no human involvement and at minimal

149 See id. at 282-83, 285; see also Jones v. United States, 565 U.S. 400,420 \& n.3 (2012) (Alito, J., concurring).

${ }_{150}$ See Knotts, 460 U.S. at $277-79$.

151 See id. at 284.

162 See id. at 281-82, 284-85; see also Jones, 565 U.S. at 429 n.10 (Alito, J., concurring) (noting limitations and fallibility of beeper technology in Knotts).

${ }^{153}$ See Jones, 565 U.S. at 413-14 (Sotomayor, J., concurring); id. at 431 (Alito, J., concurring).

154 See id. at 408-09, 411-12 (majority opinion).

${ }^{155}$ See id. at 427, 429-30 (Alito, J., concurring). 
cost. ${ }^{156}$ When combined, these factors bypassed the significant practical limitations which otherwise would make prohibitive the notion of conducting extensive police surveillance of suspects' public movements in mundane cases. ${ }^{157}$ Where such factors are not involved, however, the traditional rule continues to apply after Jones, permitting warrantless location tracking of public movements.

The Court's 2018 decision in Carpenter $v$. United States reinforced this implication from Jones. ${ }^{158}$ Putting the defendant on trial for his involvement in six robberies over several months, the Government sought to establish his presence at the locations of the robberies at the time of the crimes. ${ }^{159}$ To the extent the prosecution's case used traditional means of proving those facts, such as testimony from fellow conspirators, no Fourth Amendment issue was raised..$^{160}$ But the Government also relied heavily on historical cell-site location information ("CSLI") obtained from the archived business records of two mobile phone service providers. ${ }^{161}$ After acquiring over 120 days of data comprising nearly 13,000 data points, an investigating agent testified at trial using maps marked with the crime scenes and cellular antenna sites. This testimony demonstrated for the jury how the CSLI corroborated the cooperating accomplices' testimony about the defendant's location at the pertinent times. In addition, in closing argument, the prosecutor highlighted the value of the CSLI evidence in proving the defendant's guilt beyond a reasonable doubt. ${ }^{162}$

As in Jones and Riley, the Court distinguished the information about the defendant's location used in Carpenter by emphasizing that historical CSLI is both quantitatively and qualitatively different from previous forms of police location surveillance. ${ }^{163}$ Like Jones, the massive amount of data gathered

156 See id. at 425-26, 428-31 (Alitor, J., concurring); see also id. at 403 (describing amount of data generated by GPS device attached to defendant's vehicle).

${ }^{157}$ See id. at 429-30 (Alito, J., concurring).

158 See Carpenter v. United States, 138 S. Ct. 2206, 2215, 2216-17 (2018).

159 See id. at 2212-13.

${ }^{160}$ Seven conspirators testified against Carpenter at trial. See id. at 2212. Even if the Government learned of the person's identity as fruit of an unconstitutional search, a defendant cannot assert the exclusionary rule to bar the testimony of a cooperating witness. See United States v. Ceccolini, 435 U.S. 268, 279-80 (1978).

161 See Carpenter, $138 \mathrm{~S}$. Ct. at 2212.

162 See id. at $2212-13$.

${ }^{163}$ See id. at $2217,2218-19,2220,2223$. 
about the defendant's public movements only existed by technologically bypassing resource constraints on obtaining such evidence by human observation. ${ }^{164}$ Like Riley, the existence of archived historical CSLI provided the Government with information that literally would have been impossible to obtain at common law, or even at the turn of the twenty-first century: tracking a person's public movements retroactively, not at the time of their movements, with perfect electronic recall not subject to the faults of human memory normally inherent in reconstructing past events long after they have occurred. ${ }^{165}$ Finding these distinctions to be crucial, the Carpenter majority rejected reflexive application of the third party doctrine to deprive the location information of Fourth Amendment protection simply because it originated in the companies' archived business records. ${ }^{166}$ Instead, the majority viewed the location surveillance data in Jones and Carpenter as functionally identical in their impacts at the respective trials, such that the difference in the manner of the data's acquisition in the two cases did not justify divergent doctrinal outcomes. ${ }^{167}$ Accordingly, the Court held that the use of historical CSLI to reconstruct the defendant's public movements over a period of several months breached his reasonable expectation of privacy, and thus violated his Fourth Amendment rights because it was performed without a search warrant. ${ }^{168}$

164 See id. at $2217,2219-20$.

165 See id. at 2218,2219 . Public and private security cameras and surveillance cameras, especially when their feeds are recorded and then archived for extended periods of time, raise the same issue. See, e.g., Marc Jonathan Blitz, The Fourth Amendment Future of Public Surveillance: Remote Recording and Other Searches in Public Space, 63 AM. U. L. REv. 21, 26, 45 (2013); I. Bennett Capers, Crime, Surveillance, and Communities, 40 FoRDHAM URB. L.J. 959, 963-64 (2013); Stephen Rushin, The Judicial Response to Mass Police Surveillance, 2011 U. ILL. J.L. TECH. \& POL'Y 281, 286-89 (2011).

${ }_{166}$ See Carpenter, 138 S. Ct. at 2217; see also id. at 2226 (Kennedy, J., dissenting); id. at 2260 (Alito, J., dissenting); id. at 2262 (Gorsuch, J., dissenting).

${ }^{167}$ See id. at $2216-19$ (majority opinion).

168 See id. at 2217, 2221, 2223. In Carpenter, the federal investigators obtained the historical CSLI by means of a court order issued by a magistrate judge pursuant to the Stored Communications Act ("SCA"), 18 U.S.C.A. \& 2703(d). See id. at 2212. The majority concluded that the SCA's requirements were insufficient to protect Carpenter's Fourth Amendment rights. See id. at 2221; see also id. at 2231, 2233 (Kennedy, J., dissenting); id. at 2254-56, 2261 (Alito, J., dissenting). 


\section{HOW FAR WILL THE RESURGENCE REACH?}

In light of the Roberts Court's Fourth Amendment decisions over the past decade, especially taken as a whole, it is difficult to dismiss the resurgence of the warrant requirement as happenstance or coincidence. Jones and Jardines have reinvigorated the traditional protection against physical inspections. Jones, Riley, and Carpenter have recognized that the scope of data generated by simply living everyday life in the United States in the internet-connected digital age-whether that data is created by an individual, a corporation, or a government investigator-requires new Fourth Amendment principles not only to preserve the protections that existed at common law but also to ensure equivalent protection in technological scenarios unimaginable to the Framers. And McNeely and Birchfield have emphasized the pragmatic reality that these same technological developments mean that electronically issued search warrants are easier than ever for the police to apply for, and faster than ever for judges to approve or reject, once the facts giving rise to probable cause are known.

Rather, the question is how far the Roberts Court's resurgence in the warrant requirement will extend. Is the Court mainly acting on the margins, cautiously exercising restraint in the scope of its cases and decisions, to prevent the police from making a rapid technological end-run around the longstanding constitutional and pragmatic limitations on their investigative power? ${ }^{169}$ Or are we witnessing today what will someday be remembered as the early decisions marking out a major reenvisioning of Fourth Amendment doctrines for the twenty-first century? ${ }^{170}$ We may not yet be able to predict which assessment is the more accurate one, but the answer will come as the Court becomes forced to confront four key issues in its future decisions.

${ }^{169}$ See, e.g., Orin S. Kerr, Initial Reactions to Carpenter v. United States 4 (Univ. of S. Cal. Law Sch. Legal Studies Research Paper Series, Paper No. 18-14, 2018), https://papers.ssrn.com/sol3/papers.cfm?abstract_id=3209587; Orin S. Kerr, An Equilibrium-Adjustment Theory of the Fourth Amendment, 125 HARV. L. REV. 476, 479 (2011); Orin S. Kerr, The Fourth Amendment and New Technologies: Constitutional Myths and the Case for Caution, 102 MICH. L. REv. 801, 802 (2004).

${ }_{170}$ Compare, e.g., Flast v. Cohen, 392 U.S. 83, 105-06 (1968) (decision recognizing taxpayer standing to raise Establishment Clause challenges, but which failed to mark long-term shift in doctrine), with Griswold v. Connecticut, 381 U.S. 479,499 (1963) (decision widely regarded as origin of extensive and ongoing substantive due process right to privacy doctrine). 


\section{A. Expeditious Electronic Warrants and the Impracticability Rationale}

Several of the exceptions to the warrant requirement most frequently relevant in the context of criminal investigations by the police are based on a rationale of impracticability. In recognizing these exceptions, the Court has concluded that a warrantless search is constitutionally permissible because the practical realities of these situations make it unfeasible or inappropriate to require the police to delay the search to obtain a warrant in advance, and instead, judicial review afterward is sufficient to protect Fourth Amendment interests. While the decisions in McNeely and Birchfield ruled only as to the applicability of the exigent circumstances exception in the specific context of a BAC blood draw in a DUI investigation, the Court's reasoning in those cases has potentially significant implications for all of the exceptions based on the impracticability rationale.

Some situations of exigent circumstances, of course, will continue to present the problem of impracticability no matter how fast the electronic search warrant process becomes. Hot pursuit of a fleeing, dangerous felony suspect, for example, should not be ceased even if a search warrant to enter a residence could be obtained in a matter of minutes, because even a brief delay creates risks such as the taking of hostages or a barricaded ambush or shootout. ${ }^{171}$ Likewise, a mentally unwell individual who is a danger to himself or others deserves immediate intervention, rather than risk the tragic harms that could occur while waiting even briefly for a warrant. ${ }^{172}$ On the other hand, McNeely and Birchfield correctly require that the determination of whether the destruction or loss of perishable evidence is "imminent" enough to overcome the warrant requirement depends not only on the nature of the evidence and the pace of its disappearance, but also on the likely length of any delay attendant to obtaining a warrant before securing the evidence. While it is true that moderate quantities of narcotics can be flushed down the toilet quickly, it would take considerably longer to shred a large number of paper documents or erase an

171 See, e.g., Warden v. Hayden, 387 U.S. 294, 298-300 (1967); United States v. Ibarra-Zelaya, 465 F.3d 596, 605-06 (5th Cir. 2006); Edward H. Arens, Note, Armed Standoffs and the Warrant Requirement, 59 HASTINGS L.J. 1517, 1526-27 (2008).

${ }_{172}$ See Michigan v. Fisher, 558 U.S. 45, 45, 48 (2009) (per curiam). 
entire hard drive of digital files, which might very well be deemed more analogous to the rate of naturally metabolizing of BAC. Thus, McNeely and Birchfield reemphasize the rejection of bright-line rules and the continuing importance of the longstanding totality of circumstances analysis in exigency cases. ${ }^{173}$

Other important exceptions to the warrant requirement, however, traditionally have relied upon categorical rules of impracticability rather than a case-by-case approach. Since its inception in the Prohibition era, the automobile exception has been grounded in the rationale that motor vehicles are readily mobile, and therefore evidence contained within them inherently carries the possibility that it will vanish before a search warrant can be obtained. ${ }^{174}$ The Court's cases consistently have applied this categorical rule to all motor vehicle searches regardless of the particular facts, such as a roadside traffic stop fully under the control of the police after a controlled delivery of marijuana in California v. Acevedo, and even a car secured in the impound lot at a police station in Chambers $v$. Maroney. ${ }^{175}$ Likewise, the search incident to arrest exception's categorical approach to the impracticability rationale has been applied not only to allow the police to find and secure physical items at the scene of the arrest, but also to permit subsequent laboratory testing of items recovered to determine their nature, such as the presence of heroin inside gelatin capsules found in a cigarette carton in United States $v$. Robinson or cocaine found in a bag in a jacket pocket in Arizona $v$. Gant. ${ }^{176}$

The reasoning in McNeely and Birchfield emphasizing the increasingly expeditious availability of electronic warrants calls into question the continuing doctrinal soundness of maintaining a categorical impracticability approach for these exceptions. The automobile exception is premised on the existence of probable cause anyway, so the issuance of search warrants for the subject vehicles should be expected to be routine and uneventful.

173 Birchfield v. North Dakota, 136 S. Ct. 2160, 2174 (2016); see Missouri v. McNeely, 133 S. Ct. 1552, 1559-60, 1559 n.3, 1563 (2013); id. at 1568-69 (Kennedy, J., concurring).

174 See California v. Acevedo, 500 U.S. 565, 569 (1991); California v. Carney, 471 U.S. 386, 390 (1985) (emphasizing reduced expectation of privacy in motor vehicles compared to homes).

${ }_{175}$ See Acevedo, 500 U.S. at 566-68; Chambers v. Maroney, 399 U.S. 42, 43-46 (1970).

${ }^{176}$ See supra note 98 and accompanying text. 
Chambers seems particularly dubious now that warrants can be obtained so quickly; there is little meaningful possibility that evidence will disappear from a motor vehicle in a secured police facility in the time it would take to obtain an electronic warrant. Similarly, when the occupants of a car have been or will be arrested in a roadside stop, it is difficult to see why a short delay to obtain an electronic warrant would interfere with the recovery of the criminal evidence if the car will be towed from the scene and secured in any event. Perhaps a roadside warrantless search would be suitable in some situations, such as when the officer intends to allow other occupants of the car to depart in the vehicle after seizing evidence against a single suspect-but such an assessment would be entirely consistent with abrogating the categorical approach and instead evaluating warrantless searches on a case-by-case basis.

Likewise, a categorical authorization of some warrantless searching incident to arrest is appropriate to permit the police to protect against ambush and loss of destructible evidence-which inherently must occur at the moment of the arrest to serve the purpose of that immediate inspection. On the other hand, when police have probable cause to believe that an item or substance discovered during a search incident to arrest is an illegal narcotic, a stolen good, or other criminal evidence requiring further confirmation beyond plain view, an electronic warrant easily could be obtained in the time between the arrest and the additional inquiry to confirm its nature. ${ }^{177}$ Rejecting a categorical approach for subsequent analysis of items seized during a search incident to arrest would preserve the authority of the police to search any arrestee's property by obtaining a warrant when they have a valid basis to do so, while eliminating the ability of the police to conduct fishing expeditions in the personal effects of an arrestee in the hope of stumbling across

${ }_{177}$ The Court has held that even the simple act of slightly adjusting the position of electronic equipment to read and record the serial number, then confirming whether it had been reported stolen, could not be justified under the plain view doctrine and instead constituted a separate evidentiary "search" requiring probable cause and a warrant. See Arizona v. Hicks, 480 U.S. 321, 324-25, 326-27 (1987). Under current doctrine, however, subsequent analysis of items discovered during a search incident to arrest is not subject to this limitation because that exception, not plain view, governs the additional inspection. See supra note 98 and accompanying text. 
criminal evidence, even unrelated to the crime of arrest. ${ }^{178}$ While it is true that the Court's reasoning in Riley for requiring warrants to search a device's digital data is based primarily on its assessment of the dramatically heightened risk of improper disclosure of private information compared to physical papers or effects found during an arrest, the Court's ongoing cases about digital data could result in a reconsideration of the appropriate scope of warrantless searches of physical objects as well. ${ }^{179}$

Finally, a similar concern exists under the plain view doctrine, including for searches carried out pursuant to a valid warrant. When the police are lawfully present to observe evidence and have lawful access to seize that evidence, they may take custody of what they believe to be criminal evidence on the spot without first obtaining a warrant so long as the probable cause justifying that belief is "immediately apparent" without further investigation beyond the initial observation. ${ }^{180}$ Often, this doctrine applies when the police inadvertently encounter evidence of one crime while searching for evidence of another, but it is not limited to such situations. ${ }^{181}$ Accordingly, sometimes the police will seize a fairly large quantity of evidence without a warrant and seek to justify the seizure under the plain view doctrine-and the courts must determine whether police improperly expanded a valid initial search into a new, separate search for which a warrant should have been obtained. ${ }^{182}$ This

${ }^{178}$ For example, in Gant the Court abrogated the categorical approach previously governing searches of cars incident to arrest to instead require fact-specific justification for searching the car: either to protect the police because the scene was in fact unsecured or to locate and seize evidence of the crime of arrest which could be present in the vehicle. See Arizona v. Gant, 556 U.S. 332, 343-44 (2009); id. at 352-53 (Scalia, J., concurring). In Riley, however, the Court reaffirmed Robinson's rationale that "unknown physical objects may always pose risks, no matter how slight, during the tense atmosphere of a custodial arrest;" accordingly, because "[t]he officer in Robinson testified that he could not identify the objects in the cigarette pack but knew they were not cigarettes," then "a further search was a reasonable protective measure"-that is, the subsequent warrantless laboratory testing which confirmed the presence of heroin in the gelatin capsules found in the cigarette pack. Riley v. California, 573 U.S. 373, 386 (2014).

${ }^{179}$ See Riley, 573 U.S. at 406-07 (Alito, J., concurring) (noting different treatment after Riley of physical papers and digital data carried on the person).

180 See, e.g., Minnesota v. Dickerson, 508 U.S. 366, 375 (1993); Arizona v. Hicks, 480 U.S. 321, 334-35 (1987) (O'Connor, J., dissenting).

181 See Horton v. California, 496 U.S. 128, 135 (1990).

182 See, e.g., United States v. Carey, 172 F.3d 1268, 1271, 1276 (10th Cir. 1999) (holding that discovery of over 200 image files of child pornography found while executing search warrant for narcotics offenses exceeded scope of warrant); United States v. Gray, 78 F. Supp. 2d 524, 530-31 (E.D. Va. 1999) (holding that discovery of 
problem has become especially acute in searches of digital data, where an inspection pursuant to a search warrant related to one offense, such as financial or narcotics crimes, may lead to the discovery of substantial evidence of another crime in plain view - often child pornography, the nature of which frequently is immediately apparent. ${ }^{183}$ Although the Court has yet to consider a case presenting such facts, the emphasis in McNeely and Birchfield on the ready availability of electronic warrants suggests that police should be discouraged from acquiring extensive evidence under the plain view doctrine based on probable cause alone in situations where it would have been easy to obtain a search warrant to clearly validate the continuing discovery of additional evidence and its seizure.

\section{B. "Surveillance" in the Digital Age: Aggregation, Data-Mining, and Mosaic Theory}

Long before today's sophisticated data-gathering and data-analysis technology came into being, the Court acknowledged that the ability of the Government to conduct omnipresent surveillance of anyone-or everyone-might require different treatment under the Fourth Amendment than traditional common law investigative techniques and their marginal improvement by simplistic technological enhancement. In Knotts, for example, the Court noted the defendant's contention that "the result of the holding sought by the government would be that twenty-four hour surveillance of any citizen of this country will be possible, without judicial knowledge or supervision," but rejected it because "the reality hardly suggests abuse... if such dragnet type law enforcement practices as [defendant] envisions should eventually occur, there

images of child pornography found while executing warrant for computer hacking offenses, used to obtain second warrant to search computer for child pornography, was permissible under plain view doctrine).

183 See Adam M. Gershowitz, The Post-Riley Search Warrant: Search Protocols and Particularity in Cell Phone Searches, 69 VAND. L. REv. 585, 598-99 (2016); Orin S. Kerr, Executing Warrants for Digital Evidence: The Case for Use Restrictions on Nonresponsive Data, 48 TEX. TECH L. REV. 1, 2-3 (2015); Orin S. Kerr, Searches and Seizures in a Digital World, 119 HARV. L. REV. 531, 569-70 (2005); see also, e.g., James T. Stinsman, Comment, Computer Seizures and Searches: Rethinking the Applicability of the Plain View Doctrine, 83 TEMP. L. REV. 1097, 1097-98 (2011); David J. S. Ziff, Note, Fourth Amendment Limitations on the Execution of Computer Searches Conducted Pursuant to A Warrant, 105 CoLUM. L. REv. 841, 846 (2005). 
will be time enough then to determine whether different constitutional principles may be applicable." 184

That time undeniably has arrived. The Riley Court rightly described the incredible amount of detail about a person, from mundane activities and interests to the most intimate aspects of private life, which can be gleaned from accessing and evaluating the multitude of text, images, and other data stored on smartphones or laptops or in the internet cloud accounts linked from such devices. ${ }^{185}$ But the information contained in and revealed by a person's own tangible and electronic "papers" is only one component of the data about a person generated and retained in the digital age. Just as the Court in Kyllo recognized that the use of sense-enhancing technology to make a constructive entry into a home must be subject to the warrant requirement in the same manner as physical entries, so too limiting the Fourth Amendment analysis merely to the Government's direct intrusion into stored personal data, as occurred in Riley, would ignore the substantial dangers to privacy and liberty posed by many other forms of data-driven surveillance.

Fortunately, the Court in Jones and Carpenter took important initial steps in subjecting police investigations relying upon data-driven surveillance to Fourth Amendment scrutiny. Although both cases involved data gathering about a defendant's public movements and data analysis to connect the defendant's location at certain times and places to the crimes charged, as well as a holding that the defendant's Fourth Amendment rights had been violated by the failure to obtain a search warrant before performing such extensive surveillance, ${ }^{186}$ the underlying rationale for the decisions is not limited to a person's location information. Without adopting a particular doctrinal definition like the Katz reasonable expectation of privacy test or the Jones trespass test, the Court explained the key factors justifying judicial oversight of newly developing modes of sophisticated data-driven surveillance in light of the significant differences from the investigative methods and outcomes traditionally available at common law.

184 United States v. Knotts, 460 U.S. 276, 283-84 (1983) (internal citations and quotations omitted).

${ }^{185}$ See Riley, 573 U.S. at 393-97.

186 Carpenter v. United States, 138 S. Ct. 2206, 2223 (2018); Jones v. United States, 565 U.S. 400, 404-05 (2012). 
First, data-driven surveillance allows the Government to gather vastly greater quantities of information about a person than has ever been possible before. As the concurring opinion in Jones noted, constant month-long surveillance of a suspect's public movements by police officers would be cost-prohibitive in both financial and personnel resources, except perhaps in investigations of extraordinary importance. ${ }^{187}$ The amount of data acquired in Carpenter was even larger. ${ }^{188}$ Prior to automated technological tracking and recordkeeping like GPS monitoring or historical CSLI archives, this sheer quantity of data gathering was literally unattainable in routine investigations such as those of the local drug dealer in Jones or the half-dozen store robberies in Carpenter. ${ }^{189}$ With the rapidly changing scope of advancing technology in mind, the Court declined to quantify a specific numerical boundary on the amount of data-gathering that is permissible prior to advance judicial review. The Carpenter majority concluded that the week's worth of CSLI data obtained from Sprint constituted a "search" requiring a warrant supported by probable cause. ${ }^{190}$ The Jones concurring opinion offered another perspective: when police are unsure about the extent of their authority, they should err on the side of obtaining a warrant. ${ }^{191}$

Second, data-driven surveillance also provides the Government with information of a very different qualitative nature than has ever existed previously. The real-time GPS tracker in Jones offered the investigators a zero percent error rate and offered the jury a portrait of the defendant's movements free from doubts about human perception, memory, and credibility. ${ }^{192}$ The CSLI data in Carpenter had those same

${ }^{187}$ See 565 U.S. at 429-30 (Alito, J., concurring).

188 See 138 S. Ct. at 2212.

189 Jones owned and operated a nightclub in Washington, D.C. while involved in a conspiracy to distribute cocaine and cocaine base. See Jones, 565 U.S. at 402-03. Carpenter was the leader of a conspiracy charged with the robbery of six stores. See Carpenter, 138 S. Ct. at 2212. By contrast, in the familiar case of Costello v. United States, the defendant's trial on tax evasion charges for three tax years involved the prosecution's presentation of 144 witnesses and 368 exhibits to prove the extent of the defendant's unreported income. 350 U.S. 359, 360 (1956); see also id. at 363 (rejecting defendant's constitutional challenge to grand jury's indictment based on hearsay testimony of three IRS agents summarizing evidence later produced in full at trial).

190 See Carpenter, 138 S. Ct. at 2217 n.3.

191 See Jones, 565 U.S. at 430 (Alito, J., concurring).

192 See id.; see also id. at 415-16 (Sotomayor, J., concurring). 
advantages plus the added benefit of allowing the police to retroactively reconstruct the defendant's movements long after they had occurred, when the weaknesses in memory and credibility would have been far larger hurdles for police or prosecutors to overcome. ${ }^{193}$ Again the Court declined to offer any particular definition of the qualitative nature of technologically assisted data-driven surveillance that is permissible without a search warrant. Rather, the ambiguity in this aspect of the Court's doctrinal line between police investigative activity on their own initiative and "searches" governed by the Fourth Amendment serves to reinvigorate the longstanding basis for the warrant requirement from Johnson: to create significant incentives for the police to proceed with judicial review in advance as much as possible when an indeterminate scope of privacy or liberty interests is at stake. ${ }^{194}$

The Court's decisions in Jones and Carpenter become even more significant when taking into account the potential extent of today's data-driven surveillance to reach far beyond the relatively simplistic use of such techniques in those cases. It is one thing for the police to generate or acquire a database of location points and undertake data-mining to retrieve certain particular dates and times of great utility in a particular criminal prosecution. It is something else entirely for the police to aggregate multiple sources of data, perhaps even combining several expansive databases in doing so, and then mine this aggregation to learn information that could not have been determined from any dataset individually-thereby creating information that literally did not exist anywhere in the world until the police investigation brought it into existence. While it is true that grand juries, administrative agencies, and legislative bodies possess subpoena power capable of conducting extensive investigations and amassing substantial amounts of information, those institutions have different forms of accountability and oversight compared to ordinary police activity. ${ }^{195}$ The Court's

${ }_{193}$ See Carpenter, 138 S. Ct. at 2218.

194 See supra note 20 and accompanying text.

195 The dissenting justices in Carpenter argued that the court orders issued to the cellular providers to disclose their historical CSLI records pursuant to the provisions of the Stored Communications Act were functionally equivalent to subpoenas and therefore did not violate the Fourth Amendment. See Carpenter, 138 S. Ct. at 2228-29 (Kennedy, J., dissenting); id. at 2247-57 (Alito, J., dissenting); see also id. at 2244 (Thomas, J., dissenting). The majority opinion rejected this analogy on the facts, maintaining that "this Court has never held that the Government may 
implicit acceptance of the "mosaic theory" of the Fourth Amendment thus recognizes that a police investigation which gathers and analyzes data in a manner that provides a comprehensive picture of a person's life is a form of state action worthy of stringent judicial oversight. ${ }^{196}$

Although the specific factual context is different, the Court's analysis is consistent with the conclusion that police investigative methods and outcomes achieved by data-driven surveillance can be viewed as functionally equivalent to the general warrants despised by the Framers. ${ }^{197}$ When the police can investigate anyone, anywhere, at any time in pursuit of solving crimes, no one is secure in their persons, property, or liberty. ${ }^{198}$ General warrants issued to law enforcement officers

subpoena third parties for records in which the suspect has a reasonable expectation of privacy." Id. at 2221 (majority opinion); see also id. at 2222 (addressing Alito's dissent). But see id. at 2255 (Alito, J., dissenting) (addressing the majority opinion's statement). Traditional subpoenas are distinguishable on other grounds as well. See generally WAYNe R. LAFAVE ET AL., CRIMINAL PROCEDURE § 8.7 (2018). Unlike ordinary police investigations, legislators are directly politically accountable to their constituents; administrative agencies are constrained to the specific range of subject matters within their delegation of executive authority, and most administrative subpoenas are issued pursuant to civil rather than criminal enforcement actions. Likewise, the ordinary citizens serving as jurors function as a check on prosecutorial overreach during a grand jury investigation of criminal activity, and, unlike a search warrant, the recipient of a grand jury subpoena has the opportunity to challenge the validity or scope of the subpoena before a judge prior to appearing before the grand jury. See id. $\$ 8.4(\mathrm{~b})$. The court orders issued pursuant to the SCA, by contrast, are compulsory process issued in the same manner as a warrant-an ex parte proceeding involving only the Government and the judge-but without the requirements of probable cause and particularity required for search warrants. See Carpenter, 138 S. Ct. at 2221-22; see also Historical Scholars Brief, supra note 142, at 29 . While the company receiving the SCA order may object prior to compliance if its scope is excessively broad or burdensome, the party whose data is being obtained has no notice or opportunity to be heard as to the validity or scope of the request. See Carpenter, $138 \mathrm{~S}$. Ct. at 2221; id. at 2255 (Alito, J., dissenting) (discussing 18 U.S.C.A $\S 2703(d)$ (West 2014)). Thus, the majority in Carpenter declined to apply the Fourth Amendment analysis applicable to traditional subpoenas, including from grand juries, to SCA court orders issued to facilitate ordinary police investigations.

196 See Priester, supra note 18, at 522-24; see also, e.g., Emily Berman, When Database Queries Are Fourth Amendment Searches, 102 MINN. L. REv. 577, 578 (2017); David Gray \& Danielle Citron, The Right to Quantitative Privacy, 98 MINN. L. REV. 62, 67 (2013); Orin S. Kerr, The Mosaic Theory of the Fourth Amendment, 111 MICH. L. REV. 311, 314 (2012); Matthew B. Kugler \& Lior Jacob Strahilevitz, Actual Expectations of Privacy, Fourth Amendment Doctrine, and the Mosaic Theory, 2015 SUP. CT. REV. 205, 209 (2015).

197 See Carpenter, 138 S. Ct. at 2213.

198 See id. at 2217-20; see also Historical Scholars Brief, supra note 142, at 14-28; Thomas K. Clancy, The Fourth Amendment as a Collective Right, 43 TEX. TECH L. REV. 255, 264 (2010). 
represent a paradigm case that the Fourth Amendment sought to address, and the Court rightly applies its protections not merely to the exact facts contemplated by the Framers but also to contemporary scenarios presenting the same kind and degree of threats of governmental abuse of power. ${ }^{199}$

\section{The Third-Party Doctrine and Business Records}

Concerns about the Government's ability to use vast quantities of digital data to compile a chillingly gigantic portfolio of data on a criminal suspect-or, worse, on every American-are exacerbated by orders of magnitude when the Government can acquire and analyze data not only from its own surveillance activities but also from the seemingly endless array of ordinary business records generated every second of every day in the interconnected age. Cellphone locations in real time and archived for years, internet traffic from deliberate browsing and apps running in the background, electronic financial transactions with no tangible paper trail, and a multitude of other mundane tasks in everyday affairs would provide a comprehensive portrait of an individual's entire life if they could be easily aggregated and data-mined. Under the extant third-party doctrine, however, the acquisition of business records by the police is not a "search" for purposes of the Fourth Amendment, and therefore no factual basis in articulable individual suspicion, much less a warrant, is required to obtain them-regardless of the amount of information acquired or the scope of the intimate details of a person's life thereby revealed.

The third-party doctrine's rejection of Fourth Amendment challenges to police investigations of business records originates in United States $v$. Miller, a 1976 decision regarding bank records, and Smith v. Maryland, a 1979 decision involving a record of phone numbers dialed to connect calls through a company's network. ${ }^{200}$ The Court transposed the analysis applicable to undercover agents, confidential informants, and flipped cooperating criminals-that an individual cannot claim

199 See JED RUBENFELd, FreEdom AND TIME: A THEORY OF CONSTitUTIONAL SELF-GOVERNMENT 178-95 (2001) (arguing for a "paradigm case interpretation" of the Constitution).

200 See generally Smith v. Maryland, 442 U.S. 735 (1979); United States v. Miller, 425 U.S. 435 (1976). See also Cal. Bankers Ass'n v. Shultz, 416 U.S. 21, 52-54 (1974) (rejecting Fourth Amendment challenge to subpoena provisions of Bank Secrecy Act of 1970). 
that a reasonable expectation of privacy was breached when a "false friend" betrays their confidences to the police ${ }^{201}$ - to conclude that a person equally "assumes the risk" that a business will provide evidence of transactions or interactions in its records to the police. ${ }^{202}$ In Miller, federal agents reviewed four months of account statements and microfilm archives of cleared checks, ultimately using a small number of those documents at the defendant's trial to establish purchases and a vehicle rental as overt acts in furtherance of a conspiracy. ${ }^{203}$ In Smith, anticipating that a robbery suspect would continue his pattern of phone calls taunting a previous victim, the police had the phone company install a pen register at its office to record the phone numbers dialed from the suspect's home phone-and the suspect made another call to the victim's home that very same day. ${ }^{204}$ Along with considerable evidence obtained from the suspect's home pursuant to a subsequent search warrant, the record from the pen register was introduced at his trial. ${ }^{205}$ Thus, in both cases the scope of the business records obtained by the police was small, and the amount of them used at trial even smaller.

The Court's reasoning in these decisions has been dubious from its inception, ${ }^{206}$ but the consequences of a reflexive application of the doctrine to massive quantities of digital business records have led to numerous calls to revisit or abrogate the doctrine. ${ }^{207}$ Several important points are worth noting. For

201 See Miller, 425 U.S. at 443 (citing United States v. White, 401 U.S. 745, 751-52 (1971)); Hoffa v. United States, 385 U.S. 293, 302 (1966); Lopez v. United States, 373 U.S. 427,440 (1963)).

202 See Smith, 442 U.S. at 742-45, 747; Miller, 425 U.S. at 443.

${ }^{203}$ Miller, 425 U.S. at $437-38$. The bank received a grand jury subpoena, but law enforcement agents reviewed the documents on site at the bank so that bank officers would not have to appear before the grand jury. See id.

${ }_{204}$ Smith, 442 U.S. at 737; see also State v. Smith, 389 A.2d 858, 859-60 (Md. 1978).

${ }^{205}$ Smith, 442 U.S. at 737-38.

${ }_{206}$ See Smith, 442 U.S. at 747 (Stewart, J., dissenting); id. at 748-50 (Marshall, J., dissenting); Miller, 425 U.S. at 455-56 (Marshall, J., dissenting); see also, e.g., Carpenter v. United States, 138 S. Ct. 2206, 2262-63, 2272 (2018) (Gorsuch, J., dissenting); David A. Harris, Riley v. California and the Beginning of the End for the Third-Party Search Doctrine, 18 U. PA. J. CONST. L. 895, 897-98 (2016); Priester, supra note 18 , at 525-26, $525 \mathrm{n} .190$ (citing representative scholarship).

207 See Priester, supra note 18, at 523-29; see also Brief for Petitioner at 35-53, 65-76, Carpenter v. United States, 138 S. Ct. 2206 (2018) (No. 16-402); Brief of Amici Curiae Electronic Frontier Foundation et al. in Support of Petitioner at 24-29, Carpenter, 138 S. Ct. 2206 (No. 16-402) [hereinafter EFF Brief]; Brief of Amici Curiae Empirical Fourth Amendment Scholars in Support of Petitioner at 2-14, Carpenter, 138 S. Ct. 2206 (No. 16-402); Brief of Scholars of Criminal Procedure and 
one, it is far easier for the police to access and review-or to make duplicate copies of-archived electronic business records compared to the paper files that existed at common law, or even Miller's microfilm. Digital data can be indexed, word-searched, and cross-referenced by software-a far cry from the slow and labor-intensive process of manually viewing documents to identify pertinent information or to synthesize relevant data across multiple records.

In addition, the rapid expansion of memory capacity in digital devices, much less the effectively infinite storage available in the internet's cloud, has dramatically reduced the practical limitations that previously constrained the quantity and duration of the retention of a company's records in the ordinary course of business. Gone are the days of costly expenses to maintain records archives, including renting warehouse space to store banker's boxes of old records, destroying them after time has elapsed to make room for newer files, and paying an employee or outside vendor to monitor and implement such a document retention policy. It is literally inconceivable that cellphone service carriers would retain years' worth of historical CSLI records-relating to all of their hundreds of thousands of antennae and many billions of data points of activity passing through those towers from all cellphones, including their own millions of customers as well as users accessing the network via roaming agreements with other carriers-if those records had to be kept on paper rather than as digital data stored on servers. ${ }^{208}$

And if businesses are retaining many more documents for a much longer period of time, then the police will be able to obtain access to information that previously would have disappeared long before they sought it. Just as the use of digital location data has enabled the police to construct a mosaic of a person's public movements that would have been entirely impossible even a few

Privacy as Amici Curiae in Support of Petitioner at 14-30, Carpenter, $138 \mathrm{~S}$. Ct. 2206 (No. 16-402); Brief for Technology Cos. as Amici Curiae in Support of Neither Party at 23-25, 28-33, Carpenter, 138 S. Ct. 2206 (No. 16-402).

${ }_{208}$ See Carpenter, $138 \mathrm{~S}$. Ct. at 2211-12 ("There are 396 million cell phone service accounts in the United States-for a Nation of 326 million people."); see also EFF Brief, supra note 207, at 5-10 (providing information regarding number of cell phones, number of cell sites and antennae, and quantity of data transferred over cellular networks over time, emphasizing dramatic growth in each, especially after 2010); Brief of Technology Experts as Amici Curiae in Support of Petitioner at 14-27, Carpenter, 138 S. Ct. 2206 (No. 16-402); Brief for Technology Cos., supra note 207 , at $12-23$. 
decades ago, so too the nature and longevity of digital business records has eliminated the practical constraints which would have made impossible the kind of data collection and analysis that can be done quickly and cheaply today. ${ }^{209}$

Fortunately, the Court is aware of these concerns. Concurring in Jones, Justice Sotomayor urged the Court to reconsider the doctrine in an appropriate case. ${ }^{210}$ Although the question was briefed and argued in Carpenter, ${ }^{211}$ the majority declined to expressly overrule the entire third-party doctrine or revisit in detail its underlying conceptual basis, instead distinguishing the historical CSLI records on the facts. ${ }^{212}$ Days after Carpenter was handed down, the Court denied certiorari to a petition challenging the third-party doctrine as applied to the Government's acquisition of internet protocol traffic data from an internet service provider's network while investigating a notorious internet drug trafficking kingpin known as "Dread Pirate Roberts," a reference to The Princess Bride rather than the Chief Justice. ${ }^{213}$ The prospects for the ongoing retention of the third-party doctrine might have appeared stronger if the Government had prevailed in Carpenter, but the ramifications of the Court's holding in favor of the defendant reach well beyond historical CSLI records-and the Court's review of additional cases involving digital business records is seemingly inevitable.

${ }^{209}$ Although Justice Alito recognized the implication of the Government technologically bypassing traditional limitations in Jones, he did not reach the same conclusion in Carpenter for third-party business records. See $138 \mathrm{~S}$. Ct. at 2259-60 (Alito, J., dissenting); Jones v. United States, 565 U.S. 400, 429-31 (2012) (Alito, J., concurring).

${ }_{210}$ See 565 U.S. at 417-18 (Sotomayor, J., concurring).

211 See supra note 207; Transcript of Oral Argument at 4-6, 15-17, 22-27, 41-42, 50-51, 67-70, Carpenter, 138 S. Ct. 2206 (No. 16-402).

212 See Carpenter, 138 S. Ct. at 2217, 2219-20; see also id. at 2227, 2230, 2232-33 (Kennedy, J., dissenting) (rejecting majority's arguments on third party doctrine); Kerr, supra note 169, at 12.

${ }_{213}$ See Ulbricht v. United States, 138 S. Ct. 2708, 2708 (2018) (denying petition for certiorari); Petition for a Writ of Certiorari at 11-22, Ulbricht, 138 S. Ct. 2708 (No. 17-950). Unlike the existing historical business records sought in Carpenter and similar to the pen register for telephone dialing information in Smith, the agents investigating Dread Pirate Roberts and Silk Road conducted real-time monitoring of the defendant's internet traffic under a "pen/trap order" issued pursuant to 18 U.S.C. § 3122 . See United States v. Ulbricht, 858 F.3d 71, 83-84, 94-98 (2d Cir. 2017). "The name alludes to the pseudonym of a pirate in the popular novel and film The Princess Bride that is periodically passed on from one individual to another." $I d$. at 87 n.12 (citing WILLIAM GOLDMAN, THE PRINCESS BRIDE: S. MORGENSTERN'S Classic Tale of TRUe love and High adventure (1973); The PRINCESS BRIDE (20th Century Fox 1987)). 


\section{Data is Different}

In the Court's constitutional law applicable to criminal sentencing, the aphorism "death is different" reflects the longstanding conflict among the justices over the appropriateness of imposing heightened procedural requirements and additional substantive limitations in capital cases through interpretation of the Eighth Amendment. ${ }^{214}$ An even more controversial part of that doctrine is the reliance on "evolving standards of decency" to render unconstitutional some capital sentencing practices previously permitted by the Court's precedent. ${ }^{215}$

The reality that data is different poses a similar interpretive challenge for the Court under the Fourth Amendment. This is especially true because differences between data gathering and data analysis on the one hand, and traditional modes and outcomes of police investigations on the other, will only continue to become greater over time-with the pace of change and corresponding divergence proceeding more quickly than ever before. Kyllo and Jardines are important decisions in ensuring that the march of technology does not strip away the traditional privacy and security of the home, but they involved specific investigative acts on a particular occasion to make a discrete factual finding about the contents of a home at that precise moment. Jones, Riley, and Carpenter raise the prospect of much broader, and much more disturbing, police investigations into extensive details of individuals' lives and activities over expansive periods of time. It is no surprise, therefore, that the Court has treaded cautiously in both its holdings and its reasoning during its initial forays into the future of the Fourth Amendment. ${ }^{216}$

The difficulty of this challenge is apparent from the wide range of perspectives among the justices of the Roberts Court about how to approach the Fourth Amendment analysis in data-

${ }^{214}$ See, e.g., Baze v. Rees, 553 U.S. 35, 84 (2008) (Alito, J., concurring); Murray v. Giarratano, 492 U.S. 1, 21 n.9 (1989) (quoting Ford v. Wainwright, 477 U.S. 399, $411(1986))$.

${ }^{215}$ See, e.g., Miller v. Alabama, 567 U.S. 460, 469-70 (2012); Graham v. Florida, 560 U.S. 48, 58 (2010); Roper v. Simmons, 543 U.S. 551, 560-61 (2005). And of course, criminal procedure is far from the only area of constitutional law where the Court faces the problem of applying doctrine to changing circumstances or new technology. See, e.g., South Dakota v. Wayfair, Inc., 138 S. Ct. 2080, 2090-91 (2018) (taxation of internet commerce).

${ }^{216}$ See generally CASS R. SUNSTEIN, ONE CASE AT A TIME: JUDICIAL Minimalism ON THE SUPREME COURT 3 (1999). 
investigation cases. The textual enumeration of protecting "persons, houses, papers, and effects" from "searches" that are "unreasonable" provides at least the minimum scope of Fourth Amendment rights, but the justices do not agree about how much further the constitutional protection should extend. ${ }^{217}$ Likewise, the original understanding of the Amendment's meaning may be fairly analogous in some contexts but analytically unhelpful in others. ${ }^{218}$ Even the Court's own precedent from the pre-digital era may be proving unworkable, with criticisms ranging from eliminating the third-party doctrine to the suggestion that the Katz reasonable expectation of privacy test should be abrogated in favor of limiting the scope of the doctrine to the enumerated interests. $^{219}$

Yet, the Roberts Court also recognizes the unavoidable need for the law to keep pace with changing technology, as well as society's changing perceptions of that technology. Ideally, much of the initial response to technological and social change should come from the legislature; Congress previously acted to address wiretaps and pen registers, foreign intelligence surveillance during the Cold War, and internet computer fraud. ${ }^{220}$ State

${ }^{217}$ Compare, e.g., Carpenter, 138 S. Ct. at 2213-19 (applying the Katz reasonable expectation of privacy test and corresponding case precedent to determine scope of Fourth Amendment protections), with id. at 2238-43 (Thomas, J., dissenting) (rejecting application of the Katz privacy-based doctrine in favor of limiting Fourth Amendment protections to enumerated interests).

${ }^{218}$ Compare, e.g., Florida v. Jardines, 569 U.S. 1, 11-12 (2013) (analogizing common law bloodhounds and contemporary narcotics-sniffing dogs), with Jones v. United States, 565 U.S. 400, 429-31, 429 n.10 (2012) (Alito, J., concurring) (rejecting analogy of common law location surveillance to technological GPS tracking).

219 See, e.g., Carpenter, $138 \mathrm{~S}$. Ct. at 2236 (Thomas, J., dissenting) (questioning Katz test); id. at 2264 (Gorsuch, J., dissenting) (questioning Katz test); Jones, 565 U.S. at 415-16 (Sotomayor, J., concurring) (questioning third party doctrine).

${ }^{220}$ See, e.g., Counterfeit Access Device and Computer Fraud and Abuse Act of 1984, Pub. L. No. 98-473, $\S 1030(a), 98$ Stat. 1837, 2190 (1984) (codified at 18 U.S.C. $\$ 1030$ (2012)) (Computer Fraud \& Abuse Act, first enacted in Comprehensive Crime Control Act of 1984 and subsequently expanded by amendment in 1986, 1992, 1996, 2001, and 2008); Omnibus Crime Control and Safe Streets Act of 1968, Pub. L. No. 90-351, tit. III, 82 Stat. 197, 211 (1968) (codified at 18 U.S.C.A $§ \S 2510-22$ (West 2014)) ("Title III" of the Omnibus Crime Control and Safe Streets Act of 1968 governing wiretapping and electronic surveillance, enacted in response to Berger $\mathrm{v}$. New York, 388 U.S. 41 (1967), and Katz v. United States, 389 U.S. 347 (1967)); Electronic Communications Privacy Act of 1986, Pub. L. No. 99-508, § 3121-126, 100 Stat. 1848, 1868 (1986) (codified at 18 U.S.C.A. $\$ \$ 3121-27$ (West 2014)) ("Pen/Trap Statute" applicable to pen register and trap-and-trace surveillance, enacted in Electronic Communications Privacy Act of 1986); Foreign Intelligence Surveillance Act of 1978, Pub. L. No. 95-511, \& 105(a), 92 Stat. 1783, 1790 (1978) (codified at 50 U.S.C.A. $\S \S 1801-62$ (West 2014)) (Foreign Intelligence Surveillance Act of 1978). 
legislatures have enacted important protections for data privacy as well, implicating how both law enforcement and corporations make use of "Big Data" gathering and analysis. ${ }^{221}$ In May 2018, many U.S. consumers received numerous emails or other notices regarding updates to the data-privacy policies of companies doing business in the European Union due to implementation of the General Data Protection Regulation (“GDPR"). ${ }^{222}$ Although public policy solutions enacted in statutes may not always be constitutionally sufficient, as with the already-anachronistic provisions of the Stored Communications Act at issue in Carpenter, ${ }^{223}$ it is far easier for the Court to review the terms of a comprehensive solution enacted by the legislature than to attempt to govern the field itself through constitutional interpretation.

Justice Alito has expressly urged legislative action to address Fourth Amendment concerns related to technological advancements. See Carpenter, $138 \mathrm{~S}$. Ct. at 2261 (Alito, J., dissenting); Jones, 565 U.S. at 429-30 (Alito, J., concurring).

${ }_{221}$ See, e.g., Melody Gutierrez, Gov. Jerry Brown Signs Far-Reaching California Internet Privacy Bill, S.F. CHRON. (June 28, 2018), https:/www.sfchronicle.com/ politics/article/California-lawmakers-approve-internet-privacy-13034880.php

("Under AB375, web users can demand that a business tell them what personal information it is collecting about them, whether it is selling or sharing it, and who is ending up with it. Consumers can also tell a company to delete their personal information."). An excellent discussion of the dangers of "Big Data" is found in FranK PASQUALE, THE BLACK BoX SocIETY 19-58 (2015). Privacy is just one area in which legislation to address new technologies is necessary. See, e.g., Taly Matiteyahu, Drone Regulations and Fourth Amendment Rights: The Interaction of State Drone Statutes and the Reasonable Expectation of Privacy, 48 CoLUM. J.L. \& SOC. PROBS. 265, 267-68 (2015).

${ }^{222}$ See, e.g., Kathleen Paisley, It's All About the Data: The Impact of the EU General Data Protection Regulation on International Arbitration, 41 FORDHAM INT'L L.J. 841, 846 (2018); Brian Fung, Why You're Getting Flooded with Privacy Notifications in Your Email; Everyone from Airbnb to Yelp is Suddenly Updating Their Terms of Service, WASH. POST (May 25, 2018), https://www.washington post.com/news/the-switch/wp/2018/05/25/why-youre-getting-flooded-with-privacy-

notifications-in-your-email/?utm_term=.d47d931bdcf4; Nikhil Kalyanpur \& Abraham Newman, Today, a New E.U. Law Transforms Privacy Rights for Everyone. Without Edward Snowden, It Might Never Have Happened., WASH. POST (May 25, 2018), https://www.washingtonpost.com/news/monkey-cage/wp/2018/05/25/ today-a-new-eu-law-transforms-privacy-rights-for-everyone-without-edwardsnowden-it-might-never-have-happened/?utm_term=.f566eafc755d.

${ }^{223}$ See Brief for Petitioner, supra note 207, at 49-50 (noting that 1986 enactment of and 1994 amendments to SCA "neither intended to address nor even considered CSLI, much less whether obtaining longer-term CSLI should require a warrant" and emphasizing that "Congress simply did not anticipate the contemporary ubiquity of cell phones and the volume and precision of CSLI that would be retained by service providers"). 
At the same time, these changes in legislation and social norms also may affect how the Court assesses the meaning of the Constitution. ${ }^{24}$ In many of today's data-privacy policies, a company will use the term "your data" to refer to the information that is acquired, retained, transferred, or deleted under the provisions of the policy. The typical meaning of that term has been "data that we possess about you" pursuant to Terms of Service or related adhesion contracts. In view of consumer-favorable changes required by the GDPR and similar laws, however, the meaning may be shifting toward "data about you in our records over which you have some legally enforceable rights." And it would not mark much of a shift for the meaning to become "information about you that you have a right to control and we happen to possess."

Thus, the phrase "your data" is one answer to the question "whose data?"-and possession or custody of digital information is only one aspect of the answer, just as multiple forms of legal interests in tangible and real property can exist simultaneously. ${ }^{225}$ Byrd's functional rather than formalistic evaluation of the scope of Fourth Amendment rights for a contractually unauthorized driver of a rental car is only the most recent example of the Court rejecting a legalistic or hyper-technical interpretation of the people's protection for "their" tangible papers or effects. ${ }^{26}$ In Carpenter, Justice Gorsuch suggested that the same principle may apply to digital data and business records-so that information about you could be yours in a constitutional sense even though you did not create or store it yourself. 227 Though no other justice joined his opinion in that case, the notion already is present in the Court's mind.

${ }^{224}$ See, e.g., William Baude \& James Y. Stern, The Positive Law Model of the Fourth Amendment, 129 HARV. L. REv. 1821, 1828 (2016); Nicholas A. Kahn-Fogel, The Benefits of Using Investigative Legislation to Interpret the Fourth Amendment: A Response to Orin Kerr, 9 ALA. C.R. \& C.L. L. REV. 379, 380-81 (2018); Orin S. Kerr, The Effect of Legislation on Fourth Amendment Protection, 115 MICH. L. REV. 1117, 1119-20 (2017); Richard M. Re, The Positive Law Floor, 129 HARV. L. REV. F. 313, 314 (2016).

${ }_{225}$ See, e.g., Carpenter, 138 S. Ct. at 2268-70 (Gorsuch, J., dissenting) (discussing bailments, constructive bailments, and postal mail as potential analogies for records or data held by third parties).

${ }^{226}$ See supra notes 113-117 (discussing Byrd v. United States, 138 S. Ct. 1518 (2018)).

${ }^{227}$ Carpenter, 138 S. Ct. at 2269, 2270 (Gorsuch, J., dissenting) ("Just because you entrust your data-in some cases, your modern-day papers and effects-to a third party may not mean you lose any Fourth Amendment interest in its 


\section{CONCLUSION}

Like the often-misquoted quip by Mark Twain, the conventional wisdom's assessment of the warrant requirement's demise is exaggerated.$^{228}$ So too is the conventional wisdom that conservative judges favor the police in Fourth Amendment cases-the various opinions of the justices show it to be a rather inaccurate predictor of doctrinal positions on the Roberts Court. Though he dissented in Jardines and McNeely, Chief Justice Roberts wrote the majority opinions in Riley and Carpenter. ${ }^{229}$ Justice Alito dissented in Collins as well as Jardines and McNeely, but wrote Birchfield and concurred in the defendant's favor in Jones and Riley. ${ }^{230}$ Justice Thomas has openly questioned the Katz reasonable expectation of privacy test and dissented in McNeely and Birchfield, but he also joined all three of Justice Scalia's majority opinions in Kyllo, Jones, and Jardines. ${ }^{231}$ When the majority in Maryland $v$. King authorized the use of DNA samples collected from dangerous felony arrestees not only for purposes of identification but also for comparison against archived DNA profiles from unrelated unsolved crimes, Justice Scalia wrote the strident dissent insisting that the warrant requirement should apply. ${ }^{232}$ And

contents ... [ [T]he fact that we store data with third parties may amount to a sort of involuntary bailment too.").

${ }^{228}$ In 1897, rumors of Twain's death led him to write to a newspaper reporter, "[T] LIGHTING OUT FOR THE TERRITORY: REFLECTIONS ON MARK TWAIN AND AMERICAN CULTURE 134 (1996). Twain died in 1910.

${ }_{229}$ See Carpenter, 138 S. Ct. at 2211; Riley v. California, 573 U.S. 373, 377 (2014); Missouri v. McNeely, 569 U.S. 141, 166 (2013); Florida v. Jardines, 569 U.S. 1,16 (2013).

${ }_{230}$ See Collins v. Virginia, 138 S. Ct. 1663, 1680 (2018); Birchfield v. North Dakota, 136 S. Ct. 2160, 2166 (2016); Riley, 573 U.S. at 403; McNeely, 569 U.S. at 166; Jardines, 569 U.S. at 16; Jones v. United States, 565 U.S. 400, 418 (2012). In Carpenter, Justice Alito also expressed concern that "some of the greatest threats to individual privacy may come from powerful private companies that collect and sometimes misuse vast quantities of data about the lives of ordinary Americans" as well as from governmental data gathering and analysis, and opined that legislation is the preferable means to address both of these threats. $138 \mathrm{~S}$. Ct. at 2261 (Alito, J., dissenting).

${ }_{231}$ See Carpenter, $138 \mathrm{~S}$. Ct. at 2236-41, 2244-46 (Thomas, J., dissenting); Birchfield, 136 S. Ct. at 2197 (Thomas, J., dissenting); McNeely, 569 U.S. at 176 (Thomas, J., dissenting); Jardines, 569 U.S. at 2; Jones, 565 U.S. at 401; Kyllo v. United States, 533 U.S. 27, 29 (2001).

${ }_{232}$ See Maryland v. King, 569 U.S. 435, 482 (2013) (Scalia, J., dissenting) ("Perhaps the construction of such a genetic panopticon is wise. But I doubt that the proud men who wrote the charter of our liberties would have been so eager to open their mouths for royal inspection."). Justice Breyer joined Justice Kennedy's 
Justice Gorsuch's separate opinion in Carpenter potentially suggests an even more rigorous degree of Fourth Amendment protection for digital data than the majority opinion..$^{233}$

The Roberts Court's recent Fourth Amendment decisions have resulted in a resurgence of the warrant requirement in a number of contexts, including physical inspections of persons, papers, and effects as well as location tracking of public movements by means of data-driven electronic surveillance. Furthermore, the reasoning in these decisions strongly suggests that the Court's holdings will not remain limited to the specific factual situations of those cases. Though the future development of the doctrine remains to be seen, the recent decisions viewed as a whole demonstrate that the Court and its justices take seriously the necessity of adapting Fourth Amendment doctrine to the new threats to privacy and liberty posed by police use of advanced technology and data analytics in the digital age.

majority opinion, also joined by Chief Justice Roberts and Justices Thomas and Alito; Justices Ginsburg, Sotomayor, and Kagan joined Justice Scalia's dissent. See id. at 438 .

${ }^{233}$ See Carpenter, $138 \mathrm{~S}$. Ct. at 2267-72 (Gorsuch, J., dissenting). Despite this view, Justice Gorsuch dissented because he concluded the defendant had not properly preserved the argument, instead relying only on Katz doctrine. See id. at 2272. 